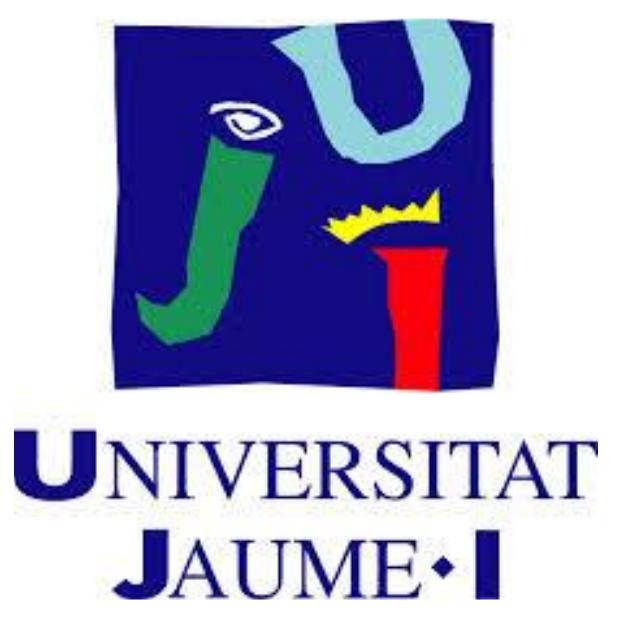

Facultad de Ciencias Jurídicas y Económicas

Departamento de Economía

\title{
Consumers' Behavior under Different Economic Scenarios: Willingness to Bargain, Willingness to Pay and Willingness to Buy
}

Doctoral Thesis presented at the doctoral program "Industrial and International Economics"

\section{Despoina Parasyri}

\author{
Supervised by: \\ Nikolaos Georgantzís \\ and \\ Konstantinos Tsagarakis
}

Castellón de la Plana, diciembre 2016 
A mis padres, amigos y compañeros que han contribuido a la elaboración de esta tesis.

A todos, gracias 


\section{Agradecimientos}

En primer lugar, quería agradecer a Nikolaos Georgantzís, porque su apoyo y dedicación, así como su confianza me han dado la fuerza de seguir caminando en este camino difícil. La oportunidad de trabajar con él y aprender de sus conocimientos y experiencia han significado para mí un enriquecimiento tanto a nivel profesional como a nivel personal.

En segundo lugar, quiero agradecer a Konstantinos P. Tsagarakis por su ayuda invaluable, sus consejos y su paciencia, porque sin él la elaboración de esta tesis de doctorado nunca sería posible. Además, quiero dar las gracias por su ayuda todos los miembros, profesores y estudiantes, del laboratorio BETECO de Departamento de Ingenieros Ambientales, Demócrito Universidad de Traca, porque me han proporcionado con todo el material necesario para hacer mi investigación y para realizar las sesiones experimentales de mis proyectos. Por último, la ayuda del profesor Robert C. Mellon del Laboratorio de Experimentación y Análisis Aplicada del Comportamiento, Departamento de Psicología, Universidad Panteion de Ciencias Sociales y Políticas, era imprescindible para la realización de un parte de esta tesis.

A continuación quiero dar las gracias a la ayuda financiera de varios proyectos de investigación, que ha hecho posible la consecución de las distintas etapas que conforman la investigación en economía experimental, en la cual se basa todo mi trabajo. Más específicamente me refiero al programa de STSM (Misión Científica a Corto Plazo) "WEBDATANET: web-based data-collection-methodological challenges, solutions and implementations " " y a la "COST Action IS1004"”. Además, quiero dar las gracias al Fondo de Pensiones de Ingenieros y Constructores Públicos de Grecia. Más que esto, estoy agradecida a "Viglia Olives S.A." por el suministro de las aceitunas de mesa y el envase.

Mis gracias más sinceras a Giorgos, Giannis, Eva, Katerina, Thodoris y a todos mis amigos, gracias por vuestro apoyo moral y psicológico en los momentos más difíciles.

Y por último, aunque no por ello menos importante, gracias a todos los participantes de mis experimentos que me han ofrecido su ayuda y la oportunidad de obtener todos los datos necesarios para mi investigación.

Despoina Parasyri

Castellón de la Plana, diciembre 2016

\footnotetext{
${ }^{1}$ http://www.webdatanet.eu/

${ }^{2}$ http://www.cost.eu/COST_Actions/isch/IS1004
} 


\section{Table of Contents}

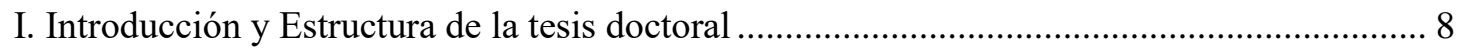

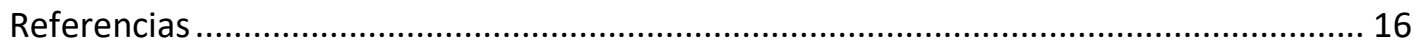

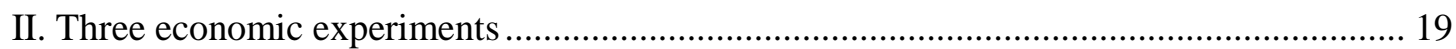

1. Cross-Gender Interaction and Communication in Ultimatum Games............................... 21

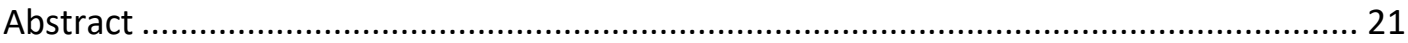

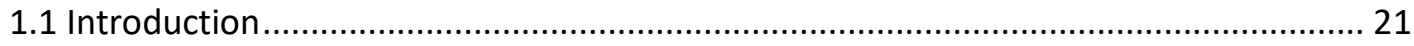

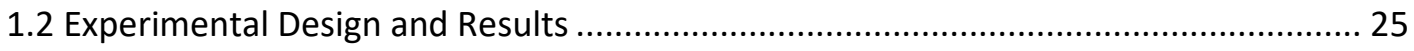

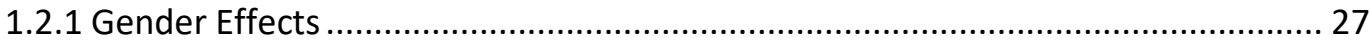

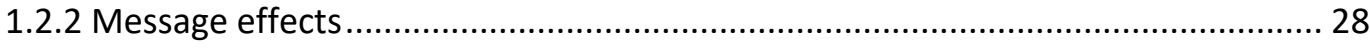

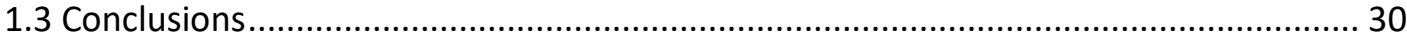

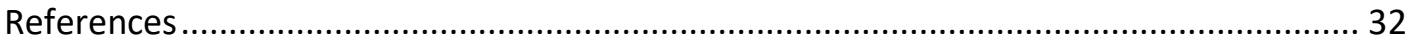

1.4 Appendix: Instructions for the Subjects (Translated from Greek) .............................. 34

2. Economics of "yuck" and "yum": willingness to consume, and pay, for food cultivated with

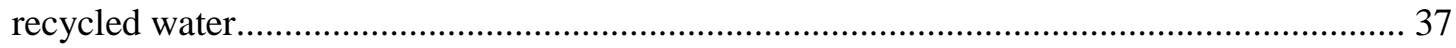

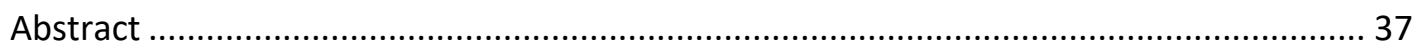

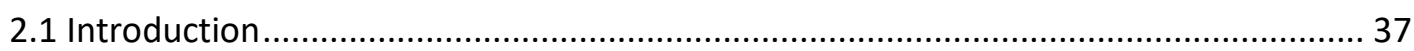

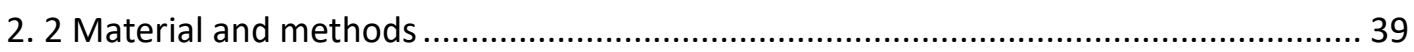

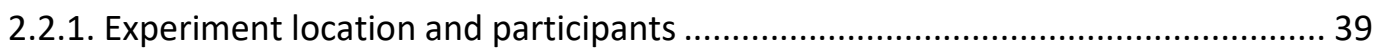

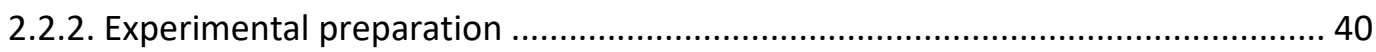

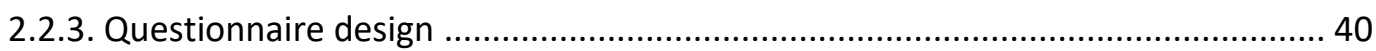

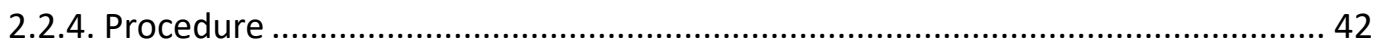

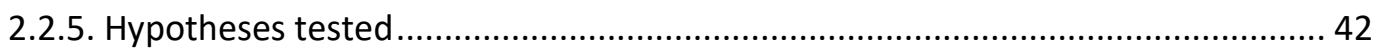

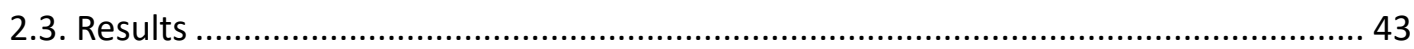

2.3.1 Perceived difference between the different samples ........................................... 43

2.3.1.1. H1: Difference in "liking" level between raisin "types" ................................... 43

2.3.1.2. H2-H5: Observed differences between the two raisin "types" .......................... 44

2.3.2 Stated willingness to purchase for the different samples...................................... 44

2.3.3 Willingness to pay for the two "types" of raisins ................................................. 45

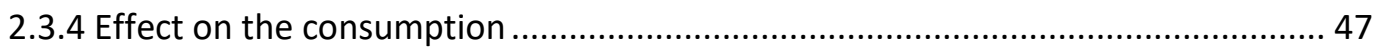

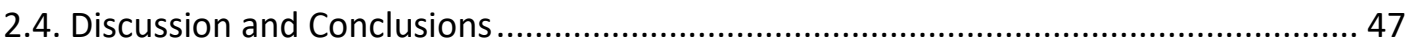

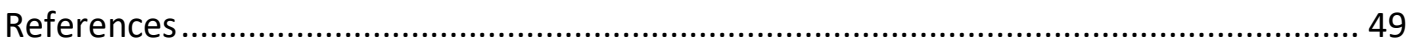

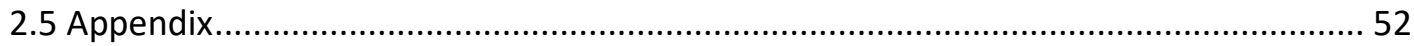

3. A comparative assessment of the Willingness to Pay between Organic and Conventional

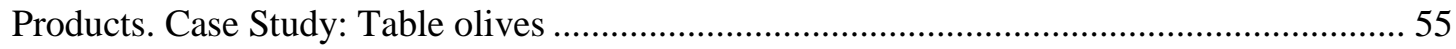




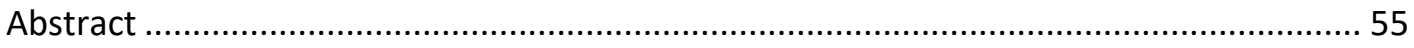

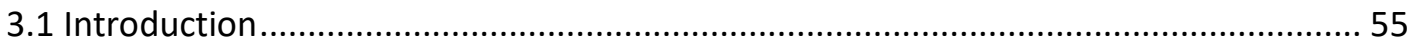

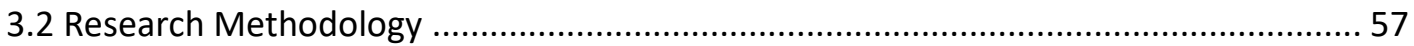

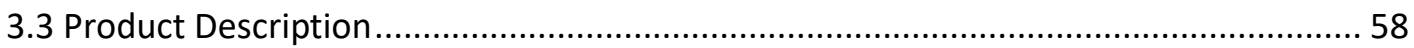

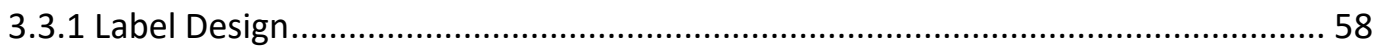

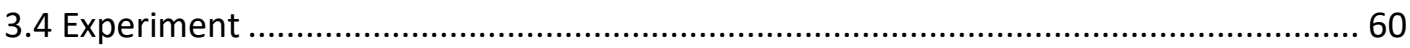

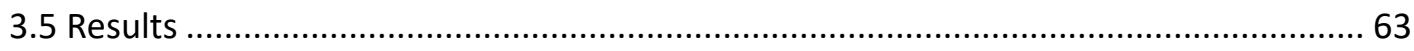

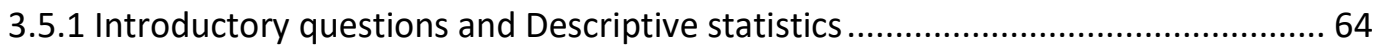

3.5.2 Socioeconomics and organic farming questions' analysis .................................... 64

3.5.3 WTP intra-stages analysis and descriptive statistics ..............................................6 65

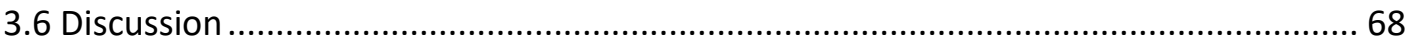

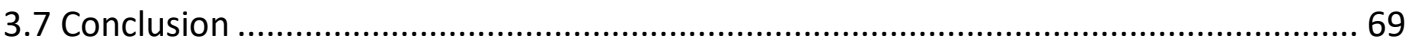

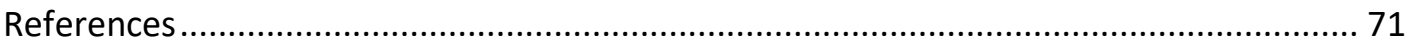

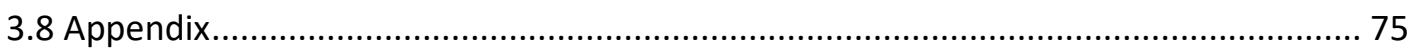


I. Introducción y Estructura de la tesis doctoral 
Esta tesis doctoral pone punto final a lo largo y sinuoso camino de investigación que se inició en el curso académico 2010/11 con la realización de los cursos de pre-doctorado y de master del Departamento de Economía de la Universidad de Granada (UGR). Esta tesis recoge tres trabajos de investigación en el campo de la economía experimental, realizados durante mis años de estudio como doctoranda en el programa de Economía Industrial e Internacional que detenta el Departamento de Economía de la Universitat Jaume I de Castellón.

El objeto de estudio y nexo de unión entre estos distintos trabajos que están presentados en los siguientes capítulos, queda perfectamente reflejado en el título de la tesis "Comportamiento de los consumidores en diferentes escenarios económicos: La disposición a negociar, la disposición a pagar y la disposición a comprar". Es bien conocido y estudiado que el comportamiento de los consumidores se afecta por varias razones. En este trabajo intento investigar algunos factores que pueden afectar este comportamiento cuando los consumidores tienen que tomar una decisión económica. Esta tesis se basa sobre tres distintos y diferentes pilares. A continuación voy a referirme brevemente a los temas que trata cada uno de los tres proyectos.

En primer lugar, quería investigar la diferencia entre la manera y la voluntad con que los dos géneros pueden negociar utilizando un típico juego de la teoría de los juegos, el juego del ultimátum. La sensación de conflicto está escrito en los genes de los seres humanos por lo que la simbiosis de géneros está lejos de ser armoniosa. A pesar del hecho de que los seres humanos son la especie más cooperativa de la tierra (Seabright, 2012), esta cooperación de ninguna manera implica la ausencia de conflictos; por el contrario, se la impone. El conflicto no siempre implica que hay intereses opuestos dentro de una asociación entre hombres y mujeres. Al contrario, implica que los intereses de los socios no están alienados por completo o simplemente que ambas partes creen que deben ser el líder en una u otra situación. Sin embargo, a fin de que surjan las sinergias entre las habilidades de un hombre y de una mujer en el contexto de una casa tradicional, surge la necesidad para los dos socios de negociar y acordar la forma en que se alcanzan los diferentes resultados y se dividen los beneficios obtenidos. Tienen que entender que mediante la cooperación tienen algo muy importante para ganar: es decir, una asociación que maximiza la utilidad de ambos socios. Metafóricamente, esta situación se asemeja a un juego del ultimátum con participantes de diferentes géneros que representan a las partes de dicha negociación. Los participantes se pueden metafóricamente ser percibidos como consumidores y las parejas que se formulan en el contexto del experimento representan la negociación entre un vendedor y un cliente que tienen que alcanzar un acuerdo. 
El juego del ultimátum, consiste en un jugador que propone un reparto de un excedente y un segundo jugador que debe aceptar o rechazar esa oferta sin posibilidad de hacer una contraoferta. Si llegan a un acuerdo se reparten el excedente como se ha acordado. Sin embargo, si no se llegarse a un acuerdo, en este tipo de juegos ninguno ganaría nada. Los datos utilizados en este experimento han sido extraídos de una situación tipo ultimátum entre jugadores de géneros diferentes y con la posibilidad de comunicación unidireccional del parte de respondedor después de la presentación de su decisión. En este caso, por tanto nuestro juego se basa en el reparto de una oferte de dinero del parte de sujeto A al que denominaremos proponente, y un beneficio para un sujeto B al que llamaremos respondedor. El reparto está condicionado a alcanzar un acuerdo, ya que existe un interés común; preferir un acuerdo a un desacuerdo. También existe un conflicto entre la partición de dicho reparto, ya que cada jugador preferirá obtener la mayor proporción posible del excedente a repartir. Más que esto, el respondedor puede expresar sus sentimientos sobre cada oferta de dinero y de esta manera guiar el proponente hacia ofertas preferibles.

En cada sesión, los sujetos fueron asignados al papel ya sea del proponente o del respondedor de acuerdo a su género. Sin embargo, los sujetos del mismo sexo tenían todos los mismos papeles en el experimento. Los sujetos fueron puestos en parejas de una vez y por toda la duración de la sesión estaban en la misma aula, pero no estaban al tanto del sujeto con que iban a negociar. El experimento fue diseñado y ejecutado mediante el software Z-Tree (Fischbacher, 2007). En cada período, la tarea del proponente era colocar una oferta de $€ X$, lo que podría ser cualquier cantidad entre $0 €$ y $20 €$, en pasos de $€ 0.1$. Los pares de proponentes $\mathrm{y}$ de respondedores fueron fijos durante el experimento. Un respondedor que fue seleccionado al azar para ser emparejado con un proponente recibió una oferta y debería aceptarla o rechazarla. Con el fin de prevenir los efectos acumulativos de la riqueza, los sujetos se les pagaron de acuerdo a sus ingresos por un período especificado al final de la sesión. En cuanto a realidad, la limitación de los activos ha predeterminado que sólo el $80 \%$ de los sujetos de cada sesión podrían ser pagados y ellos fueron recogidos de nuevo en orden aleatorio al final de cada sesión. Este hecho fue anunciado a todos los participantes al inicio del experimento.

Cada sesión incluye 4 partes dependiendo del papel de cada género en el juego, así como la presencia o ausencia de comunicación. Sin embargo, a los proponentes no se les permitió a responder al mensaje enviado por los respondedores, ya que era imperativo mantener secreto el contenido de los mensajes entre los miembros de cada grupo. Hemos adoptado este tipo de diseño experimental con el fin de buscar posibles efectos que los mensajes podrían tener sobre el comportamiento de los participantes en las sub-secciones con comunicación, mientras que en el mismo tiempo estábamos en busca de un impacto del mensaje en las sub-secciones sin comunicación cuando se llevaron a cabo después de los subsecciones con mensajes. 
En segundo lugar, quería investigar el efecto del descriptor "regar con agua reciclada" en el nivel de la preferencia y de la disposición a pagar por productos alimenticios. El aumento intensivo en la producción agrícola de las últimas décadas ha contribuido en la explotación de los recursos hídricos. Por otra parte, la forma de vida moderna ha dado lugar a la producción de grandes rutas de flujo de aguas residuales. En consecuencia, en muchas regiones con escasez de agua, efluentes de plantas de tratamiento de aguas residuales (agua reciclada) se reutilizan para el riego de cultivos agrícolas (Angelakis et al., 1999; Anderson, 2003; Paranychianakis et al., 2006). El reciclaje del agua, sobre todo para el riego, se ha desarrollado como una fuente alternativa de agua con el fin de ahorrar agua dulce y de eliminar la escasez de agua. Además, sirve para aumentar el regadío y al mismo tiempo para cumplir con los criterios de calidad del agua requerida a fin de que los riesgos ecológicos y peligros para la salud pública se eliminen (Paranychianakis et al., 2015).

En el campo de la comercialización, la aceptación pública es el principal obstáculo en el uso de agua reciclada o en el consumo de productos agrícolas regados con agua reciclada. Persuadir a la gente a usar el agua reciclada se ha demostrado ser muy difícil y la aceptación pública del agua sigue siendo el principal desafío en la implementación exitosa de reutilizarlo (Nancarrow et al., 2008). A pesar del llamado "factor rechazo" (yuck factor), que se ha destacado en la literatura (por ejemplo, Menegaki et al., 2009) desde la década de los 1970, se ha avanzado poco en la investigación dirigida a explorar la conexión entre el uso de agua reciclada y la evitación, relacionada con el disgusto, a consumir productos que incorporan en su proceso de producción este tipo de agua.

Otro factor que quería investigar en este trabajo es la disposición a pagar por el agua reciclada o para productos alimenticios para los que agua reciclada se ha utilizado durante el proceso de producción. En varios trabajos sobre este tema, se ha encontrado que, las personas más y mejor informados sobre el agua reciclada y los productos regados de este tipo de agua, están dispuestos a pagar más por esta y por sus subproductos (Tsagarakis \& Georgantzís, 2003).

Hasta donde sabemos, ninguno de los trabajos publicados sobre la relación entre los descriptores de la calidad del agua y de la voluntad de utilizarlo ha tratado el consumo real de los productos agrícolas regados con agua reciclada. En este estudio hemos abordado este tema. En concreto, se investigó, con un experimento, el efecto de los descriptores de procedencia del agua (irrigado con "agua limpia" o con "agua reciclada") en la evaluación del producto y en la disposición a pagar por ello. Por esta rezón, se pidió a cada participante en el experimento de probar pasas de uva a partir de dos cajas, diseñadas e impresas profesionalmente, casi idénticas. La única diferencia entre las cajas (y su contenido) fue el descriptor del agua con que los frutos fueron supuestamente irrigados; una caja indicó que la 
viña, donde se produjeron las pasas se regó con " agua limpia", mientras que la otra caja indicó que se regó con "agua reciclada". El propósito de este diseño fue determinar si la información relativa al origen del agua sola (agua limpia o reciclada) era suficiente para alterar la percepción de los participantes sobre la calidad de dichos productos agrícolas.

Después de terminar el proceso de cata, los participantes se encargaron de responder a un breve cuestionario, preguntando su opinión sobre el sabor, la apariencia, la calidad y las diferencias entre los dos "tipos" de pasas. Además, se registró la disposición de los participantes para comprar y para pagar por las pasas de la misma calidad de los que estaban en cada caja.

Una serie de hipótesis se pusieron a prueba. Las hipótesis eran que, si bien las muestras son de calidad idéntica, la información de origen (agua limpia y agua reciclada) afectaría a juicio de los participantes de una manera consistente con el llamado "factor asco".

En tercer lugar, y dado mi interés sobre temas ambientales, quería investigar la disposición a pagar para productos orgánicos y la diferencia entre esta disposición en un escenario hipotético y uno real. La conciencia medioambiental durante las dos últimas décadas, junto con la preocupación por la calidad de los productos y la demanda de alimentos más seguros han llevado a los consumidores a cuestionar las prácticas agrícolas modernas. Se ha encontrado, que los consumidores consideran las características perceptibles de los alimentos, como la apariencia y el sabor, como los factores más importantes en la elección de los alimentos (Magnusson et al., 2001). Sin embargo, existe una fuerte evidencia de que otros atributos de alimentos, no tan fácilmente tangibles, como por ejemplo su calidad y proceso de producción, se están volviendo cada vez más importantes (Torjusen et al., 2001). Esta nueva forma de pensar ha dado lugar a un aumento en la demanda de productos agrícolas orgánicos, que son percibidos como menos perjudiciales para el medio ambiente y más saludables que los producidos convencionales (Williams \& Hammit, 2001).

En muchos casos, los consumidores parecen estar dispuestos a pagar más dinero para la compra de productos, especialmente frutas y verduras, que son libres de sustancias tóxicas y son beneficiosos para la salud (Tranter et al, 2009; Batte et al, 2007). En la literatura se han llevado a cabo varias investigaciones centradas específicamente en la determinación de la disposición del consumidor a pagar por algunas características específicas de los bienes (Combris et al., 2002). La mayoría de estos estudios, están basados en un escenario hipotético con el objetivo de proporcionar evidencia sobre cómo los signos de calidad influyen en la calidad percibida del producto, pero no ponen los consumidores en virtud de un dilema real a través de la cual se puede observar su verdadera disposición a pagar (DAP) por estos productos y su disposición para comprarlos. ¿Qué ocurre cuando los consumidores se enfrentan a los verdaderos precios de tales productos? ¿Su voluntad declarada de pago difiere de su real? 
Para detectar las posibles diferencias en la DAP entre la declarada DAP y la real DAP utilizamos un experimento de elección dicotómica poniendo los participantes a seleccionar entre un producto orgánico y un producto convencional del mismo tipo. El producto que hemos utilizado es las aceitunas comestibles. Técnicamente, este experimento se asemeja a un mecanismo de votación entre los dos productos. En este mecanismo de votación lo que se requiere, a excepción de la limitación a sólo dos alternativas, es la suposición de que las personas perciben que sus utilidades podrían verse afectadas por el resultado de la votación.

La novedad de esta investigación es que es la primera en validar experimentalmente datos de la encuesta sobre la DAP por un solo atributo ambiental de un producto de mercado cuando se utiliza el descriptor "orgánico", con el fin de definir su origen. Junto con las comparaciones de la inclinación de los consumidores a favor de los productos orgánicos, el diseño del experimento tiene como objetivo comparar la DAP declarada y la real a nivel individual. En este contexto, la DAP declarada de cada participante en la parte hipotética se compara con su disposición a pagar real en una sesión experimental, diseñada para ser económicamente viable y apropiada para replicar una situación de elección real dentro de un laboratorio.

La validez de las respuestas a la pregunta hipotética " ¿Si le dieron un par de precios, cuál de los dos paquetes de aceitunas comprarías? "fue probada usando un dentro-participantes experimento. En este contexto, los participantes tenían que responder a una serie de escenarios/combinaciones de precios. Una tabla de quince (15) diferentes pares de preciosescenarios fue dado a ellos y tuvieron que elegir para cada precio-escenario cuál de los dos productos estaban dispuestos a comprar. En cada escenario, el precio de las aceitunas orgánicas toma un valor diferente que va desde abajo hasta bastante por encima del precio de los productos convencionales. El precio de los últimos se mantiene en línea con el precio en lo que el producto se vende realmente en el mercado minorista. En la etapa de la sesión de DAP real, se les dieron a los participantes una dotación de $5 €$ parte de la cual, como lo han sido instruidos, se deberían gastar para comprar uno de los dos paquetes de aceitunas disponibles.

A lo largo de la historia económica, había la percepción que la Economía no es una ciencia experimental, pero durante las últimas décadas los experimentos se han convertido en uno de los métodos preferidos de investigación, en particular en el campo de la teoría de los juegos y en lo de la economía de comportamiento. El motivo de adoptar la metodología experimental es porque permite el estudio controlado de entornos estratégicos interactivos por sujetos. Los participantes de los experimentos son voluntarios y toman decisiones siguiendo las instrucciones de cada escenario económico, es decir siguiendo las normas creadas por el experimentalista. Las decisiones de los sujetos forman la base de datos que se utilizan para 
obtener los resultados y las respuestas en las hipótesis que están puestas en prueba en cada experimento y para desarrollar varias conclusiones sobre las teorías económicas. Los participantes son incentivados monetariamente o con productos actuales (como por ejemplo en el tercero experimento), dependiendo de sus decisiones.

Todos los datos aquí utilizados son recopilaciones extraídas de varios experimentos, en los que los sujetos eran estudiantes de las ramas de ingeniería y de psicología. Cabe mencionar que dichas ramas han elegido porque los estudiantes no tienes conocimientos de teoría económica y de teoría de juegos y por esta razón sus reacciones y sus respuestas son imparciales.

El software estadístico para el análisis de datos ha sido principalmente el SPSS, aunque también nos hemos apoyado en otros programas informáticos como Stata. En el análisis de datos procedemos, en primer lugar, a la descripción de las variables del conjunto de datos objeto de estudio. Obtenemos de esta manera unas primeras conclusiones sobre las características de dicho conjunto, a partir de un estudio estadístico descriptivo apoyado con histogramas, gráficos de distribución acumulada o temporales. En segundo lugar, y dada la naturaleza de la muestra, calculamos test no paramétricos, como Mann-Whitney, Wilcoxon, Kolmogorov-Smirnov o modelos probit. Los test en los que se rechaza la correspondiente hipótesis nula al nivel de significación del $10 \%, 5 \%$ y $1 \%$ están señalados en las tablas con *, ** y***, respectivamente. 


\section{Referencias}

Anderson, J. (2003) The environmental benefits of water recycling and reuse. Vol. 3. Water Science and Technology: Water Supply (pp. 1-10).

Angelakis, A. N., Marecos Do Monte, M. H. F., Bontoux, L., \& Asano, T. (1999). The status of wastewater reuse practice in the Mediterranean basin: Need for guidelines. Water Research, 33(10), 2201-2217.

Batte, M. T., Hooker, N. H., Haab, T. C., \& Beaverson, J. (2007). Putting their money where their mouths are: Consumer willingness to pay for multi-ingredient, processed organic food products. Food Policy, 32(2), 145-159.

Combris, P., Lecocq, S., \& Visser, M. (1997). Estimation of a hedonic price equation for Bordeaux wine: does quality matter? The Economic Journal, 390-402.

Fischbacher, U. (2007). Z-Tree: Zurich toolbox for ready-made economic experiments. Experimental Economics, 10(2), 171-178.

Magnusson, M. K., Arvola, A., Koivisto Hursti, U.-K., Åberg, L., \& Sjödén, P.-O. (2001). Attitudes towards organic foods among Swedish consumers. British Food Journal, 103(3), 209-227.

Menegaki, A. N., Mellon, R. C., Vrentzou, A., Koumakis, G., \& Tsagarakis, K. P. (2009). What's in a name: Framing treated wastewater as recycled water increases willingness to use and willingness to pay. Journal of Economic Psychology, 30(3), 285-292. doi: 10.1016/j.joep.2008.08.007

Nancarrow, B. E., Leviston, Z., Po, M., Porter, N. B., \& Tucker, D. I. (2008) What drives communities' decisions and behaviours in the reuse of wastewater. Vol. 57. Water Science and Technology (pp. 485-491).

Paranychianakis, N., Salgot, M., Snyder, S. A., \& Angelakis, A. (2015). Water reuse in EU states: necessity for uniform criteria to mitigate human and environmental risks. Critical Reviews in Environmental Science and Technology, 45(13), 1409-1468. 
Paranychianakis, N. V., Nikolantonakis, M., Spanakis, Y., \& Angelakis, A. N. (2006). The effect of recycled water on the nutrient status of Soultanina grapevines grafted on different rootstocks. Agricultural water management, 81(1-2), 185-198.

Seabright, P. (2012). The war of the sexes: How conflict and cooperation have shaped men and women from prehistory to the present

Torjusen, H., Lieblein, G., Wandel, M., \& Francis, C. A. (2001). Food system orientation and quality perception among consumers and producers of organic food in Hedmark County, Norway. Food quality and preference, 12(3), 207-216.

Tranter, R., Bennett, R. M., Costa, L., Cowan, C., Holt, G., Jones, P., Vestergaard, J. (2009). Consumers' willingness-to-pay for organic conversion-grade food: Evidence from five EU countries. Food Policy, 34(3), 287-294.

Tsagarakis, K. P., \& Georgantzís, N. (2003) The role of information on farmers' willingness to use recycled water for irrigation. Vol. 3. Water Science and Technology: Water Supply (pp. 105-113).

Williams, P. R., \& Hammitt, J. K. (2001). Perceived risks of conventional and organic produce: pesticides, pathogens, and natural toxins. Risk analysis, 21(2), 319-330. 
II. Three economic experiments 


\title{
1. Cross-Gender Interaction and Communication in Ultimatum Games ${ }^{3}$
}

\begin{abstract}
In this paper, we focus on bargaining within male-female pairs, the most pervasive partnership in humankind since prehistory. We analyze data from an ultimatum game experiment played by subjects of different genders, and parallel to this, we introduce a one-way communication protocol according to which the responders can send short messages to the proposers after making their decisions. The analysis shows that gender and message effects exist and that males can bargain more effectively.
\end{abstract}

Keywords: ultimatum game, gender effect, message effect, communication, negotiation, bargaining

\subsection{Introduction}

Partnerships between a male and a female within a household are the most ancient and most pervasive type of partnership among humans. Pairs of men and women forming families cooperate and negotiate on a daily basis. Economic self-interest plays an important role in intrafamily gender relations; as Agarwal (1997) states, bargaining is part of everyday life for a couple and occurs when the partners have different preferences and needs. Of course, there are restrictions on the bargaining ability of the two partners. For example, in some countries, because of social perceptions, women are considered to be inferior to men and this strongly affects their bargaining power. In these countries, women have to negotiate on a daily basis in order to gain something that for men is considered as granted. Within-household bargaining plays a major role in the social life of both genders because it can strongly define the ability to bargain in the society in general and simultaneously determines someone's bargaining power.

The majority of papers on within-household bargaining focus on women's bargaining power and its determinants. In this paper, we study the bargaining ability of both genders. In the literature, it is usually assumed that men have everything that they want in a relationship and scarcely need to bargain. On the other hand, women are presented as being in an inferior position; thus, they have to bargain very often. What happens when men have to bargain too?

\footnotetext{
${ }^{3}$ This paper was published as "Georgantzís, N., Parasyri, D., \& Tsagarakis, K. (2016). Inter-gender interaction and communication in ultimatum games. Applied Economics Letters, 1-5. doi: 10.1080/13504851.2016.1237725"
} 
Do they achieve their goal or are women are better at that, putatively being more experienced in bargaining? We will try to provide evidence consistent with the possible answers.

The sense of conflict is written in the genes of human beings. From prehistory until modern times, the coexistence of the two genders has provoked different and remarkable results, from epic battles to epic loves. These facts state that the symbiosis of genders is far from harmonious. That is because, as Paul Seabright (2012) says in his book The War of the Sexes, human beings are the most cooperative species on earth. Cooperation by no means implies the absence of conflict; on the contrary, it imposes it. Many observers provide evidence that sexual conflict is a by-product of our civilization. Conflict does not always imply that there are opposing interests within a male-female partnership. It implies that the partners' interests are not alienated completely or simply that both partners believe that they should be the leader in one situation or another.

However, in order for the synergies between a man's and a woman's abilities to be achieved in the context of a traditional household, a need emerges for the two partners to negotiate and agree on the way in which different outcomes are reached and the shares of the benefits obtained are divided. They have to understand that by cooperating they have something really important to gain: that is, a partnership that maximizes the utility of both partners. Metaphorically, this situation resembles a UG with agents from different genders representing the negotiating parties. In this paper, we will focus on an ultimatum game between different genders, giving the responders the possibility to send a short message to the proposers expressing their feelings about the offer they received after submitting their decision.

As Manser and Brown (1980) and Pollak (2005) mention in their studies, in a relationship, independently of whether it is under the concept of a marriage or not, the couple tries to maximize a utility function that will maximize their utility under the utility possibility frontier. In our study, this frontier is the amount of money given to one of the two partners in each pair of players. These pairs can be considered as simulations of non-married couples, the members of which have an independent utility function and are called to bargain between each other in order to maximize their personal utility. In this scenario, the decision process in our UG experiment can be defined as one through which the two partners try to reach a combination of utilities located on the utility possibility frontier and through which they must decide on the allocation of resources and the distribution of gains. In our study, this utility frontier is defined by the 20 euros offered to the proposer as non-labor income. Any combination that maximizes both utilities and at the same time satisfies the utility frontier will lead to acceptance. If the responder is not satisfied with the offer received, meaning that he is not maximizing his utility, he will reject it and as a result no agreement can be reached. The agreed combination is Pareto 
efficient because, as described by Doss (2013), the outcome of the bargaining process is one in which no one could ameliorate his position without making someone else in the household worse off. Our experiment approaches a type of housekeeping allowance system as presented in Jan Pahl's (1995) study. Pahl defines this system as one in which the husband gives money to his wife for housekeeping expenses and he keeps the rest.

The behavior of subjects in the economic experiments depends, among other things, on their gender and consequently on the risk preferences of each gender. ${ }^{4}$ Concerning the role of gender in the ultimatum game, Eckel and Grossman (2001) found that women appeared to be indifferent concerning the gender of the other player and that they were more generous than men. In the one-shot ultimatum game experiment conducted by Solnick (2001), the offers made to female players by both sexes were lower and the responders of both sexes intended to accept lower offers when facing female proposers.

The majority of the experimenters who have chosen to study gender differences in ultimatum bargaining use gender in combination with other factors, such as risk preferences or altruistic behavior, which have been observed in former studies. Our research differs from other similar studies that use sessions with pairs of the same and different genders, because we focus on the gender differences emerging when players are faced with the opposite gender. Furthermore, the introduction of communication between players in combination with the above structure makes this design unique given the fact that very few bargaining experiments have been conducted for this scenario.

Pollak (2005), in his study, states that the major problem with the studies that use observed differences across couples in the control of non-labor income is located in the assumption that this income is exogenous. That happens because many aspects can affect the proportion of the income controlled by the wife or the husband. As a solution to this problem, he proposes a controlled experiment that will provide additional resources to husbands in some families and to wives in others. That is exactly the structure of our experiment if we can assume that the pairs of our research represent bargaining families.

Many studies provide evidence that men are more risk loving than women (for example Croson \& Gneezy, 2009). As García-Gallego et al. (2008 and 2012) state, although we cannot reach a unanimous opinion concerning gender effects in competitive environments, women appear to be more risk averse, they tend to reject offers more often and they tend to make lower

\footnotetext{
${ }^{4}$ Croson and Buchan (1999) and Eckel et al. (2008) found that men and women behave less differently in a risk-free environment, comparing evidence from experiments with and without risk-related gender differences in bargaining behavior.
} 
offers. Furthermore, in the same study, the authors reject the hypothesis that gender effects in an ultimatum game are due to differences in risk attitudes.

In the majority of the papers involving communication between players, it was found that the knowledge of the feelings of the players strongly affects the behavior of the participants. In an experiment conducted by Andersson et al. (2010), in which the proposer had the opportunity to communicate with the responder and in which they examined the persuasion effects in experimental ultimatum games, they found that the pay-off of the proposers increased when they had the opportunity to communicate with the responders by sending short messages before making their decision. In the same study, it was observed that players who sent more persuasive messages received higher pay-offs. In experiments conducted by Xiao and Houser (2005 and 2009), in which the responders had the opportunity to send a short message along with their decision, the researchers observed that the rates of rejection of unfair offers were significantly lower, but that we cannot know the real emotion behind any of the messages. This opinion has a point because we can never be sure about the thoughts of the participants. In our experiment, we chose messages as a method of communication in order to ensure privacy and because verbal or eye contact can bias the results. ${ }^{5}$ Several researchers have found that it is preferable to hold uncomfortable discussions (such as demanding money or expressing bad feelings about something) over the telephone or by short messages rather than in person because it reduces the effort that has to be invested in mastering feelings. We studied the contents of messages and classified them according to their purpose. The majority of the players chose to communicate and their main purpose was to demand a specific amount of money and to convince their partner to increase the offer. They countenanced the increases and expressed their dissatisfaction when they failed to happen. Additionally, we saw the impact that each message had on the offer and the decision in the subsequent round.

We chose to insert communication into our experiment because we wanted to compare the changes, if any, it produces in the subjects' behavior between the pre- and the post-message stage. Such an experiment was performed by Rankin (2003), who states that when responders had the capability to send messages, this fact led to lower offers, higher rejection rates and as consequence lower pay-offs. In our experiment, we attained similar results but only for female subjects. The behavior of the subjects changed during the experiment because they tried to adapt their decisions in the attempt to predict the next move of the other player. As Winter and Zamir (1997) state in their book, the proposers adapt their offers to the responders' rejection and the responders adapt their rejections to the proposers' behavior.

\footnotetext{
${ }^{5}$ As Ellingsen and Johannesson (2008) found in their experiment, knowing that someone is angry does not produce the same level of shame as facing the angry person or even having to read angry messages.
} 
By expressing an emotion that makes the receiver feel selfish or guilty about his offer, as stated by Houser (2011), the senders of the messages managed to change the receivers' behavior and as a consequence receive larger amounts of money, at the same time as reducing the rejection rate. Several psychologists have studied emotions and the meaning of different emotional expressions. If the responder in a UG is motivated by envy, he will probably reject an offer, and if he is motivated by indignation, he will feel pleasure as a result of this rejection. Elster (1998), in his study, shows that a feeling of indignation can be a feeling of envy in disguise and the dynamics of those emotions cannot be reflected in simple cost- benefit models.

\subsection{Experimental Design and Results}

In the literature, we can find plenty of ultimatum game experiments that focus on gender differences, using communication. In some of them, pre-play communication is used, while in other, like ours, researchers use post-decision communication. Pre-play communication has a clear strategic objective, which is to convince the other player to act in a favorable way. On the other hand, post-play communication is a way to send a signal about what the responder expects the proposer to do in subsequent periods and has a clear objective of influencing the proposer's forthcoming offers. Without the ability to disentangle these two effects, we use post-decision communication, which has been studied much less in the literature so far. The results reported here were obtained from fourteen sessions of the ultimatum game with sixty periods each and the subjects were recruited among the students of the School of Engineering at the Democritus University of Thrace. Of the fourteen sessions, ten had eight participants and the remaining four had six participants. The experiment was conducted at the Business \& Environmental Technology Economics (BETECO) laboratory of the Department of Environmental Engineering in Thrace, Greece.

In every session, the subjects were assigned the role of proposer or responder according to their gender. All the subjects of the same gender had the same role in the experiment. Of the 104 subjects participating in the experiment, $50 \%$ were male and $50 \%$ were female. Common written instructions were handed to them. ${ }^{6}$ The subjects were paired once for the whole session, and all the subjects were in the same room but unaware of the subject with whom they were bargaining. The experiment was designed and executed using the z-Tree software (Fischbacher, 2007). In each period, the proposer's task was to place an offer of $€ X$, which could be any amount between $€ 0$ and $€ 20$, in steps of $€ 0.1$. Random proposer-responder pairs were formed within fixed, independent, matching groups. These groups were stable across all the periods of

\footnotetext{
${ }^{6}$ Instructions translated from Greek are provided in the appendix.
} 
the experiment. A responder who was randomly chosen to be matched with a proposer received an offer and was called to accept or reject it. In the case of acceptance, the responder gained $€ X$ and the proposer $€ 20$-X. Otherwise, they both earned nothing. In order to prevent cumulative wealth effects, the subjects were paid according to their earnings in one period, which was randomly selected at the end of the session. ${ }^{7}$ Furthermore, because of the limited assets, only $80 \%$ of the subjects of each session were paid and they were randomly selected at the end of each session. This was announced to all the participants at the beginning of the experiment.

In each session, for 30 rounds of the game, the female subjects were given the role of proposer, and for the remaining 30 rounds, they changed their role and became responders. Each session consisted of 4 parts according to the role of each gender in the game and the presence or absence of communication. The structure was the following. There were 15 rounds in which the female subjects had the role of proposer in a repeated ultimatum game without communication. For another 15 rounds, the female subjects remained in the role of proposer but now they received a message from the male responders after the decision to accept or reject their offer. The proposers were not allowed to respond to the message sent by the responders. Secrecy was guaranteed concerning the content of the communication among the members of each group. For 15 rounds, the male subjects became the proposers while the female responders sent them a message, and for the remaining 15 rounds, the male subjects were proposers in a repeated ultimatum game without communication. In order to avoid ordering effects, the subjects were randomly entered in the above sub-sessions. Tables 1.1 and 1.2 present the mean values of the proposed amounts of money, the earnings of the proposers and responders calculated from successful transactions and the percentage of accepted offers by subject role and gender. In the whole data set, there were no observed offers equal to zero. Furthermore, in the analysis, we took into consideration that the offer and decision in a certain period for each subject are a function of the previous offers and decisions because fixed pairs bring history into play for all the periods after period 1 .

Table 1.1: Mean values of offers, earnings and acceptance frequencies with male proposers

\begin{tabular}{lcccc}
\hline & Offers & Proposer earnings & Responder earnings & Acceptance \\
\hline Without message & 9.16 & 10.11 & 9.88 & $82.94 \%$ \\
With message & 8.73 & 10.05 & 9.93 & $72.05 \%$ \\
\hline Overall & 8.95 & 10.08 & 9.90 & $77.50 \%$ \\
\hline
\end{tabular}

\footnotetext{
${ }^{7}$ Rankin (2003) followed the same strategy regarding payments.
} 
Table 1.2: Mean values of offers, earnings and acceptance frequencies with female proposers

\begin{tabular}{lcccc}
\hline & Offers & Proposer earnings & Responder earnings & Acceptance \\
\hline Without message & 7.62 & 11.54 & 8.45 & $67.80 \%$ \\
With message & 9.11 & 10.25 & 9.84 & $75.64 \%$ \\
\hline Overall & 8.37 & 10.89 & 9.15 & $71.72 \%$ \\
\hline
\end{tabular}

\subsubsection{Gender Effects}

Possible gender effects were checked for the offers and earnings of the subjects in subsessions with and without communication and for both roles. The Mann-Whitney U two-tailed test was performed for this purpose.

\subsubsection{Result 1: The gender effect on offers}

In the sub-sessions without messages, the amounts offered by male subjects were $16.8 \%$ higher than those offered by female subjects $(p<0.001)$. In the sub-sessions with messages, the amounts offered by female subjects were $4.1 \%$ higher than those offered by male subjects. This is statistically significant $(p=0.052)$ for the confidence level of $5 \%$. From the above, we can say that gender plays a role in the offered amounts in both sub-sessions with and sub-sessions without communication.

\subsubsection{Result 2: The gender effect on earnings in sub-sessions without communication}

We studied earnings by gender in both sub-sessions, with and without communication, for the two roles of the subjects. The earnings were calculated only from the successful transactions. We found that in the sub-sessions without messages, female proposers earned more than male proposers $(p<0.001)$. On the contrary, in the sub-sessions with messages, there is no statistically significant difference in the earnings for the two genders in the role of proposer $(p=0.565)$.

When they had the role of responder, in the sub-sessions without communication, male subjects gained more money than female subjects $(p<0.001)$. In those with messages, there is no statistically significant difference in the earnings for the two genders $(p=0.540)$. These earnings were calculated, as above, from the successful transactions in the experiment. These findings indicate that gender plays a role in the pay-offs of the subjects, independently of their role, only when they play a UG without communication. 


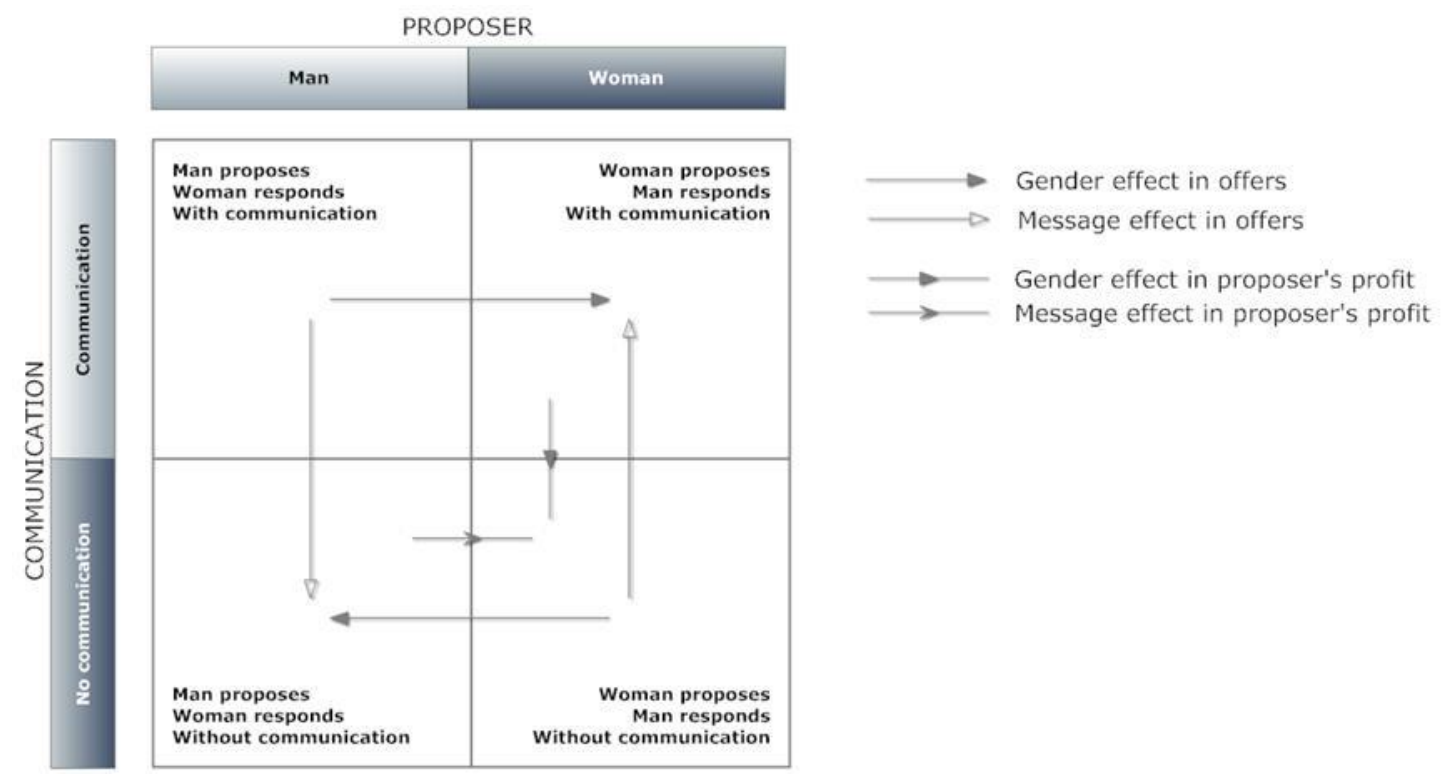

Figure 1.1 Gender and message effects in offers and proposer profits (the arrow directions indicate statistically significant increases in the corresponding amounts)

\subsubsection{Message effects}

Possible message effects were checked for the offered amounts and for the earnings of the subjects in sub-sessions with and without communication and for both roles. The Wilcoxon test was performed for this purpose.

\subsubsection{Result 3: The messages had different effects on the offers of each gender}

By performing an analysis of the possible message effects, we wanted to find out whether the offered amount increased ex ante, meaning that the messages do not affect the beliefs of proposers concerning the responders' minimum acceptable offers, or whether proposers raise their offers ex post, after having observed the responders' behavior in the message sub-sessions.

In sessions in which the female subjects were proposers, there is a statistically significant increase in offers in the message sub-sessions $(p<0.001)$. From Table 1.2, we can see that there is an increase of $€ 1.49$ in the offers in the sub-sessions with messages. On the contrary, in the rounds in which men had the role of proposer, there is a decrease of $€ 0.43$ in the amounts offered in the sub-sessions with messages $(p=0.007)$. In order to guarantee that the differences in offers across pre- and post-message sub-sessions are not due to other dynamics, like learning, we also tested and rejected, by analyzing the string of offers of each subject, the existence of learning behavior across the sub-sessions of the experiment.

\subsubsection{Result 4: A decrease in the proposer's earnings in message sub-sessions when the} proposer was a female subject 
In sessions in which female subjects had the role of the proposer, their earnings, calculated from the successful transactions, decreased by $11.17 \%$ in the sub-sessions with messages $(p<0.001)$. On the contrary, when testing the difference in the earnings of male subjects, in the sub-sessions in which they had the role of proposer in the game, the decrease of $0.5 \%$ in their earnings presented in Table 1.2 is not statistically significant $(p=0.873)$. These results make sense in both cases if combined with the differences in offers and acceptance percentages.

In the sub-sessions with female proposers, an increase in offers after receiving a message led to an increase in the percentage of acceptance, an increase in the earnings of the responders and a decrease in the earnings of the proposers. In the cases in which males were proposers, a decrease in offers after receiving a message led, as expected, to a decrease in the percentage of acceptances, but the difference between proposer and responder earnings is not statistically significant (Mann-Whitney test for the responders' earnings: $p=0.858$ ). ${ }^{8}$

\subsubsection{Result 5: The messages had a positive effect on the responders' average earnings when males had the role of responder, increasing their earnings}

We tested the differences in proposers' and responders' earnings calculated from successful transactions across the pre- and post-communication periods. Comparing the data of the sub-sessions, we find that the messages sent by male subjects increased their earnings $(p<0.001)$. On the contrary, in sub-sessions in which messages were sent by females, we find that this fact does not affect their earnings significantly $(p=0.858)$.

\subsubsection{Result 6: Female responders failed to convince male proposers to give them the amount of money they demanded}

From the evaluation of the messages sent by each gender, as described in the introduction, we find that female subjects failed to convince male proposers to offer them their desired amount of money. This led to a decrease in the acceptance percentage in the message sub-sessions when the female players were the responders. The messages of female subjects showed that they had no strategy about the level of acceptable offers, behavior that led them to accept smaller amounts than requested in many cases. The male proposers showed behavior that tended to ignore the requests of the female subjects. On the other hand, when males were sending messages, they almost always received their desired amount of money. That fact led to an increase in the acceptance percentage by $7.8 \%$.

\footnotetext{
${ }^{8}$ For those effects, see Figure 1.1.
} 


\subsubsection{Result 7: Being female and having the opportunity to send messages decrease the willingness to accept an offer}

In order to analyze an acceptance or rejection decision with respect to gender and the presence of messages, we use the following Probit model, in which the dependent variable is the decision of the participants and takes the value 1 for acceptance and the value 0 for rejection. ${ }^{9}$ Table 1.3 displays the results.

Table1.3: Probit results for the probability of acceptance

\begin{tabular}{ll}
\hline Decision & Coefficient Est. \\
\hline Offer & $0.14598^{* *}$ \\
Female & $0.14924^{*}$ \\
Message & $0.192^{* *}$ \\
Female $\times$ Message & $-0.2083^{*}$ \\
Constant & -0.6785 \\
Observations Pseudo R2 & 0.1282 \\
Prob>chi2 & $<0.001$ \\
\hline
\end{tabular}

Notes: Offer: offered amount of money, Female: 1 for female subjects and 0 for male subjects, Message: 1 for the presence of messages and 0 for the absence of messages, Female $\times$ Message: dummy product of gender and message, Significance: **1\%, *5\%

Interpreting this table, we reach the following results:

1. An increase in offers will increase the probability of acceptance $(P>|z|<0.001)$.

2. Being a female increases the probability of accepting an offer $(P>|z|=0.045)$.

3. The presence of post-decision messages increases the probability of accepting an offer $(P>|z|=0.007)$.

4. Being a female participant in the sub-sessions with messages decreases the probability of accepting an offer $(P>|z|=0.043)$.

\subsection{Conclusions}

Human life is founded on exchange. Many centuries of interaction and evolution within the roles of husband and wife have not sorted out the existence of conflicts, nor have they led to an ability to communicate in a way that would minimize the conflict. Bargaining processes are dominant in the majority of actions in modern societies. The existence and stability of those processes between men and women are a fundamental building block. In fact, this type of negotiation, in its different forms and occasions of occurrence, determine the outcome of several social processes, including the level of development in the society as a whole. In this

\footnotetext{
${ }^{9}$ Andreou et al. (2011) used the same model in order to examine the willingness to accept a given wage.
} 
paper, we use the well-known set-up of ultimatum bargaining to establish some interesting facts, focusing on the role of post-decision communication as a means of informing the other party of one's emotions following a given outcome.

The analysis shows that gender does play a role in the amount of money offered in both sub-sessions. Male subjects, after reading the messages, tend to offer more, but on the other hand, females are more generous in the sub-sessions with communication. There is also a message effect, which affects the level of offers. Females are most prone to changing their attitude and increasing their offers when knowing the intensions and wishes of the other player. However, they rely on their capability to convince males to offer them the desired amount of money in the communication sub-sessions and do not hesitate to decline undesired offers. From this, it is evident that the females in our experiment negotiate less aggressively than the males. The answer to the question that we posed in the introduction, wondering whether women, who are more experienced in bargaining, negotiate better than men, is that there is no evidence to prove that. This result supports the theory that women run away from negotiation, action that may be based not just on inhibition but also on a shrewd assessment of how their behavior will be viewed by others.

The overall effect of the presence of communication is positive for male subjects, increasing their profits and their willingness to accept an offer. Studies have shown that men negotiate harder with women than they do with other men, whether through prejudice, habit or conscious coordination. 


\section{References}

Agarwal, B. (1997) "“Bargaining' and gender relations: Within and beyond the household." Feminist Economics, 3 (1), 1-51.

Andersson, O., Galizzi, M.M., Hoppe, T., Kranz, S., der Wiel, K.V. \& Wengström, E. (2010) "Persuasion in experimental ultimatum games." Economics Letters, 108 (1), 16-18.

Andreou, A., Andreou, S.N., García-Gallego, A. \& Georgantzís, N. (2011) “An ultimatum wage bargaining experiment on trade union efficiency." Bulletin of Economic Research, 65 (4), 354-361.

Croson, R. \& Buchan, N. (1999) “Gender and culture: International experimental evidence from trust games." American Economic Review, 89 (2, Papers and Proceedings of the One Hundred Eleventh Annual Meeting of the American Economic Association), 386-391.

Croson, R. \& Gneezy, U. (2009) “Gender differences in preferences.” Journal of Economic Literature, 47 (2), 448-474.

Doss, C. (2013) "Intrahousehold bargaining and resource allocation in developing countries." World Bank Research Observer, 28 (1), 52-78.

Eckel, C., De Oliveira, A.C.M. \& Grossman, P.J. (2008) “Gender and negotiation in the small: Are women (perceived to be) more cooperative than men?" Negotiation Journal, 24 (4), 429-445.

Eckel, C. \& Grossman, P. (2001). "Chivalry and solidarity in ultimatum games." Economic Inquiry, 39 (2), 171-188.

Ellingsen, T. \& Johannesson, M. (2008) "Anticipated verbal feedback induces altruistic behavior." Evolution and Human Behavior, 29 (2), 100-105.

Elster, J. (1998). "Emotions and economic theory.” Journal of Economic Literature, 36 (1), 4774.

Fischbacher, U. (2007) "Z-tree: Zurich toolbox for ready-made economic experiments.” Experimental Economics, 10 (2), 171-178.

García-Gallego, A., Georgantzís, N. \& Jaramillo-Gutiérrez, A. (2008) "Ultimatum salary bargaining with real effort." Economics Letters, 98 (1), 78-83. 
García-Gallego, A., Georgantzís, N. \& Jaramillo-Gutiérrez, A. (2012) "Gender differences in ultimatum games: Despite rather than due to risk attitudes." Journal of Economic Behavior and Organization, 83 (1), 42-49.

Houser, D.E.X. (2011) "Classification of natural language messages using a coordination game." Experimental Economics, 14 (1), 1-14.

Manser, M. \& Brown, M. (1980) "Marriage and household decision-making: A bargaining analysis." International Economic Review, 21 (1), 31-44.

Pahl, J. (1995) "His money, her money: Recent research on financial organization in marriage." Journal of Economic Psychology, 16 (3), 361-376.

Pollak, R.A. (2005) "Bargaining Power in Marriage: Earnings, Wage Rates and Household Production.” [Online] Available from: http://www.Nber.org/papers/w11239

Rankin, F.W. (2003) “Communication in ultimatum games.” Economics Letters, 81 (2), 267271.

Seabright, P. (2012) The War of the Sexes: How Conflict and Cooperation Have Shaped Men and Women from Prehistory to the Present. Princeton University Press.

Solnick, S. (2001) “Gender differences in the ultimatum game.” Economic Inquiry, 39 (2), 189200.

Winter, E. \& Zamir, S. (1997) "An Experiment with Ultimatum Bargaining in a Changing Environment." The Hebrew University, Center for Rationality and Interactive Decision Theory.

Xiao, E. \& Houser, D. (2005) "Emotion expression in human punishment behavior." Proceedings of the National Academy of Sciences of the United States of America, 102 (20), 7398-7401.

Xiao, E. \& Houser, D. (2009) "Avoiding the sharp tongue: Anticipated written messages promote fair economic exchange.” Journal of Economic Psychology, 30 (3), 393-404. 


\subsection{Appendix: Instructions for the Subjects (Translated from Greek)}

Thank you for your participation in this experiment. The goal of this experiment is to study the economic behavior of people, under specific economic conditions. The instructions are very easy and if you follow them carefully, there is a chance of winning an amount of money in a confidential way; given the fact that none of the other participants will know the amount of money you have gained. In this experiment, there are no correct or incorrect answers. However, bear in mind that your decisions will affect the amount of money that will be gained by both you and the participant with whom you will be paired anonymously and randomly. You can ask me questions if you have any doubts about the process of the experiment by raising your hand. The time of the experiment is not infinite, so please try to respect the given timeline in each stage of the experiment.

1. In order to ensure anonymity and confidentiality, a random number, a yellow tag, will be given to you at the beginning of the experiment.

2. There are two types of players: the players of type A and the players of type B. You will know your type of player from the beginning of the experiment. All the players with the same gender will have the same role. This role, at some point during the experiment, will change suddenly and simultaneously for all the players of the same gender.

3. Each player of type A will be matched randomly with a player of type B during the experiment. The identity of the participant with whom you will be matched will be completely unknown to you before, during and after the experiment. You will know only his/her gender. The pairs of the players will not change for the duration of the experiment.

4. The experiment will have 60 rounds.

5. Instructions for player type A:

In this experiment, you will be a player of type A. You and another player, with whom you will be matched randomly, a player of type B, will have the chance to win an amount of money. The decision-making procedure will be the following. The player of type A (this is you) will offer an amount X from a total of $€ 20$ to the player of type B. The offers can be any amount between $€ 0$ and $€ 20$ in steps of $€ 0.10$ (it is accepted that there will be integer amounts and subdivisions of them, e.g. $€ 2, € 4$, $€ 5.10$ and $€ 13.20$ but not $€ 3.25$ and $€ 15.17)$. If the player of type $B$ accepts the offer, he or she will gain $€ X$ and you will gain $€(20$-X). If he or she rejects the offer, neither of the two players will gain money in this round. This procedure will be repeated for 60 rounds. 
6. Instructions for player type B:

In this experiment, you will be a player of the type B. You and another player, with whom you will be matched randomly, a player of type A, will have the chance to win an amount of money. The decision-making procedure will be the following. The player of type $A$ will offer an amount $X$ from a total of $€ 20$ to the player of type $B$ (this is you). The offers can be any amount between $€ 0$ and $€ 20$ in steps of $€ 0.10$ (it is accepted that there will be integer amounts and subdivisions of them, e.g. $€ 2, € 4, € 5.10$ and $€ 13.20$, but not $€ 3.25$ and $€ 15.17)$. You have to decide whether to accept or reject this offer. If you accept the offer, you will gain $€ X$ and the player of type A will gain $€(20-X)$. If you reject the offer, neither of the two players will gain money in this round. This procedure will be repeated for 60 rounds.

\section{Additional instructions for player type B:}

At some point during the experiment, you will have the possibility but you will not be obliged to send a short confidential message to the player of type A with whom you have been matched.

7. At the end of the experiment, $80 \%$ of you will receive an amount of money according to your decisions during the experiment in a confidential and private way. The players who will be paid will be chosen randomly. The amount of money that you will receive will be the amount each player has gained during a round of the experiment. This round will be chosen randomly and will be different for different players (even if the profits were zero in the chosen round for this player).

8. In order to be sure that you have completely understood the procedure, please answer the following questions, based on the experiment in which you will participate. If you have any doubts, please do not hesitate to ask me questions by raising your hand.

\section{Questionnaire}

a) If the player of type $A$ offers $€ 4$ to the player of type B and the player B accepts:

What is the amount of money the player of type $\mathrm{A}$ has gained in this round?.

What is the amount of money the player of type $B$ has gained in this round?

b) If the player of type B rejects the offer of player A: 
What is the amount of money the player of type A has gained in this round?........................

What is the amount of money the player of type $B$ has gained in this round? 


\title{
2. Economics of "yuck" and "yum": willingness to consume, and pay, for food cultivated with recycled water
}

\begin{abstract}
In this paper we describe an experiment testing the effect of the descriptor "irrigated with recycled water" on the level of preference and willingness to pay for food products. Each participant in the experiment was asked to taste raisins from two nearly identical professionally designed and printed boxes. The only difference between the boxes (and their contents) was the descriptor of the water with which the fruits were putatively irrigated: one box indicated "irrigated with freshwater" while the other box indicated that the vineyard where the raisins were produced was irrigated with recycled water. The results of the experiment are interpreted as being consistent in general with the so-called "yuck factor," that is, that the descriptor "recycled water" elicits disgust or inhibits appetite, thus reducing preference for or willingness to pay the product so described; however, a minority of participants actually preferred the product designated as recycled, and these individuals were more likely to purchase and to pay more for such earth-friendly goods.
\end{abstract}

Keywords: Raisins; yuck factor; yum factor; irrigation; willingness to pay; willingness to buy; recycled water

JELClassification Codes: C12; C91; 3290

PsycINFO classification: $3660 ; 4070$

\subsection{Introduction}

The intensive rise in agricultural production of the last decades has contributed in the exploitation of water resources. Moreover, the modern way of life has resulted in the production of large wastewater flow routes. Consequently, in many regions with water scarcity, effluents from wastewater treatment facilities (recycled water) are reused for the irrigation of agricultural crops (Angelakis et al., 1999; Anderson, 2003; Paranychianakis et al., 2006). Water recycling, particularly for irrigation, has been developed as an alternative source of water in order to save freshwater and eliminate water shortages, to increase the irrigated land and at the same time to meet the required water quality criteria to eliminate ecological and public health risks (Paranychianakis et al., 2015). Furthermore, recycled water contains essential nutrients that might stimulate growth and increase yield (Klein et al., 2000; Maurer et al., 1995). However, 
during the irrigation with recycled water, the nutrients' concentrations should be carefully monitored to prevent harmful effects on plant performance (Magesan et al., 1998) or to the environment. Recycled water is produced in different qualities based on level of treatment, with each quality level being appropriate only for a specific range of uses (i.e. for restricted irrigation, unrestricted irrigation, industrial use, landscape irrigation, etc.; Tsagarakis et al., 2004). The levels of treatment refer mainly to the recycled water concentrations in pathogens, nutrients and organic matter (i.e. primary secondary and advanced treatment).

Recycled water will not be used, and will not be permitted, to replace the conventional water sources for irrigation, unless all the standards imposed by the legislation are met (Salgot et al., 2003; Gerba and Rose, 2003). There is a continuous update and optimization of water reuse criteria (Blumenthal et al., 2000; World Health Organization (WHO), 2006; Queensland Government, 2008; Paranychianakis et al., 2015) by individual states and agencies in order to ensure that reused water reaches the standards of high quality and safety. But despite all these safety guidelines, there is evidence of existence of the so called "yuck factor" when people taste food whose origin is deemed to be from "impure sources" or food for which previously impure sources were used in production, such as recycled water coming from domestic wastewater treatment (Po et al., 2005).

In the marketing field, public acceptance is the main obstacle in the use of recycled water or in the consumption of agricultural products irrigated with recycled water. Persuading people to use recycled water has proved to be very difficult and the public acceptance of the water remains still the principal challenge in the successful implementation to reuse schemes (Nancarrow et al., 2008). Although some members of the general community are willing to use recycled water, according to some researches (e.g. Water Corporation of WA 2003; Kaercher et al., 2003; Menegaki et al., 2009), the majority of them hesitate to do so. As Tsagarakis et al. (2007) have shown, it is more difficult to establish the acceptance of recycled water itself than of recycled water-based products such as foodstuffs. While the so called "yuck factor," (e.g., Menegaki et al., 2009) exists in the literature since the 1970s, little progress has been made in research aimed at exploring the connection between the use of recycled water and the disgustrelated avoidance to consume products which incorporate in their production process this kind of water. There is, however, evidence that the closer the recycled water to human contact or ingestion is, the less people are likely to utilize it (Australian Research Centre for Water in Society, 2002).

Another factor that has to be investigated is the willingness to pay for recycled water or for food products for which recycled water has been used during the production process. It has been found that, as the people get more and better information about the recycled water and the products irrigated from it, the more they are willing to pay for recycled water and its byproducts (Tsagarakis and Georgantzís, 2003). 
Furthermore, it has been observed that education levels and levels of environmental awareness are positively correlated with willingness to pay for products irrigated with recycled water (Genius et al., 2005; Menegaki et al., 2007; Tziakis et al., 2009). But at the same time, in other studies there is evidence that people are eager to pay for recycled water only in cases in which there is a scarcity of freshwater (e.g. Bakopoulou et al., 2010) or if they otherwise benefit from this action, e.g. by contingent reduction in outdoor water restrictions (Dupont, 2013). Moreover, it has been reported that experienced users of treated water are willing to pay more money for it when they are aware of the fact that the production process is costly (Hurlimann, 2009). To our knowledge, none of the published work on the relation between water quality descriptors and willingness to use or pay has involved the actual consumption of agricultural products irrigated with recycled water. In this study we addressed this issue. Specifically, we investigated the independent effect of water provenance descriptors (irrigated with "freshwater" or "recycled water") on the evaluation and the willingness to pay for raisins.

\section{2 Material and methods}

\subsubsection{Experiment location and participants}

The experiment was conducted in two different academic departments with different curriculums and consequently different levels of knowledge on wastewater treatment as well as of relations between environment and behavior; at the Business \& Environmental Technology Economics (BETECO) laboratory of the Department of Environmental Engineering at Democritus University of Thrace, and at the Laboratory of Experimental and Applied Behavior Analysis of the Department of Psychology at Panteion University of Social and Political Sciences in Athens. The reason for selecting these two disciplines is to investigate potential differences from the recruited participants who do their studies in those two departments. The engineering students are mostly men and science/technology oriented, while the psychology students are mostly women and social science oriented. In both laboratories, indoor thermal comfort conditions and restricted noise levels were maintained.

The sample consisted of 160 students (80 from each department) who responded to invitations to participate. The participants were informed that one box contained raisins irrigated with freshwater and the other box contained raisins irrigated with recycled water. This information was also presented on the boxes, which were otherwise identical. The two boxes in fact contained raisins from the same freshwater-irrigated source. The purpose was to determine if information concerning the water source alone (fresh or recycled water) was sufficient to alter the participants' perception of the quality of agricultural products. 


\subsubsection{Experimental preparation}

In order to comply with the standards of the professional packaging, two different boxes were designed and created by a publishing firm. The boxes had information concerning the expiration date, the content product, the preservation conditions, the net weight (50 gr), the country of origin accompanied by a Greek flag, and full contact information (production region, telephone, fax and email address). A plausible brand name was given (Kandylis Soultanina, which defines the place of origin of the product) and a trademark was designed. The opening and the bottom side of the pack had a printed photo of raisins. A photo of grapes was also printed on one side of the box. At the bottom, a facsimile barcode was inserted. The only difference between the two box types was that on one of them it was written, in large font, "Contains raisins produced from grapes irrigated with freshwater (here after called box Type FW) whereas the other box type indicated that it "Contains raisins produced from grapes irrigated with recycled water certified for irrigation (here after called box Type RW). Figure 2.1 shows the two different packages that were created for this experiment. Several hundred of them were produced. All raisins contained in boxes of both types were sourced from the Consortium of Cooperative Organizations of Soultanina of Crete. It was the highest quality product from the most recent raisin production, irrigated with freshwater. No matter the package type, the contents were identical in both "qualities" of raisins used in the experiment.

\subsubsection{Questionnaire design}

A structured questionnaire was designed expressly for the purpose of this experiment (see appendix). The questionnaire consisted of four parts. In the first part we asked the participants general questions about the raisins that they have tasted. We asked them if they like raisins in general, we investigated their preference level for the two sample types tasted, and we asked them to select the differences that they found, if any, between the two samples from a given list of potential differences. 


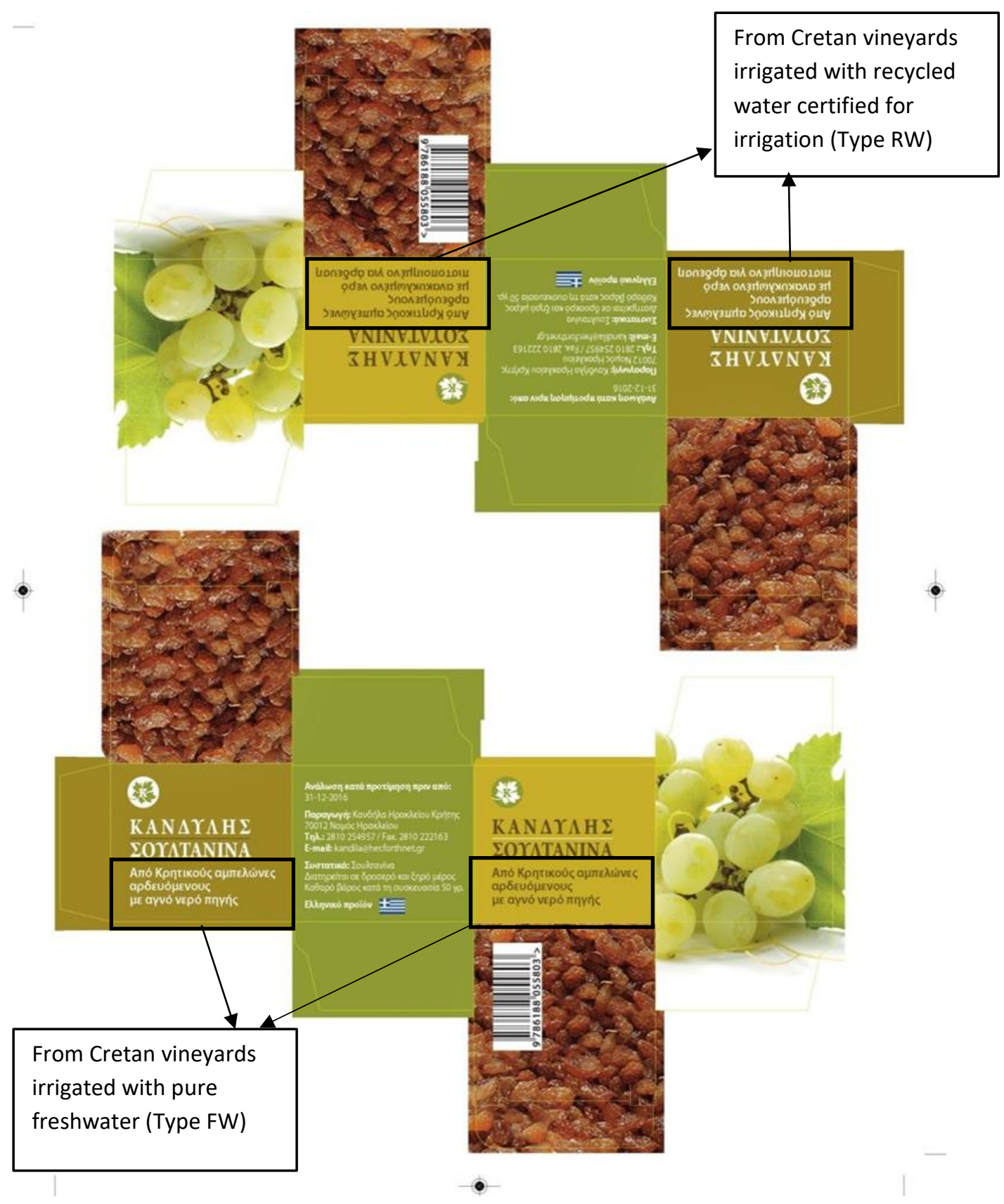

Figure 2.1 The two different versions of packages (unfolded boxes before entered in the cutting machine) which we created for the experiment

The second part of the questionnaire was designed to assess the participants' willingness to buy and their willingness to pay for each "type" of raisins. The participants were then asked to indicate their certainty concerning their willingness to buy the raisins of the two boxes. Subsequently, the participants were asked to state the amount of money they were willing to pay in order to buy each of the "types." A reasonable price of $0.5 €$ (keyed to current market value) was provided as an anchor value for the other Type; for example: 
"If this box of raisins with $50 \mathrm{gr}$ weight derived from grapes irrigated with freshwater costs $0.50 €$ how much would you be willing to pay to buy an identical box of raisins from grapes irrigated with recycled water certified for irrigation?"

The third part of the questionnaire collected personal data of each participant such as gender, age and personal income. In a fourth part of the questionnaire in which the experimenter recorded the consumption (in grams) from each box.

\subsubsection{Procedure}

When the participant entered the laboratory he/she was instructed to sit down on a specific desk. Then written instructions were provided and read by the experimenter, as follows:

"In this experiment you will be asked to taste two samples of raisins. You will be given two different boxes which contain raisins. On each of them is printed the content origin. The one of the two boxes contains raisins originated from Cretan vineyards irrigated with freshwater, while the other one contains raisins originated from Cretan vineyards irrigated with recycled water certified for irrigation. From each sample you can try as many raisins as you like without any restriction on the amount of consumption. Once the tasting has been finished you will be asked to complete a questionnaire in which we inquire your opinion about the raisins you've tasted."

Then, the experimenter provided verbal information to the participants about the definition, the origin and the purification process of the certified recycled water so all participants had the minimum required information, in order to participate in this experiment. Afterwards, the participant was instructed to taste from the first box, and then from the second box. The sequence of the boxes (Type FW and RW) was different across participants in order to avoid possible ordering effects in participants' preference and consumption levels. After finishing the tasting process, the participant was instructed to respond to a short questionnaire, concerning among other issues, his/her opinion about the taste, appearance, quality and differences of the two "types." Furthermore, the participant's willingness to buy and to pay for raisins of the same quality as that were in each box was recorded. Then the participant was debriefed and dismissed. Afterwards, the experimenter weighed the two pre-weighed boxes in order to record the quantity that had been consumed from each box.

\subsubsection{Hypotheses tested}

A number of hypotheses $\left(\mathrm{H}_{\mathrm{i}}, i=1, \ldots 8\right)$ were tested. The hypotheses were that, although the samples are of identical quality, the source information (FW-RW) would affect the participants' judgment in a manner consistent with the so-called "yuck factor".

H1: The participants like more the raisins of Type FW (although the two samples are the same) 
H2: The participants state difference in the taste between the raisins of Type FW and those of Type RW.

H3: The participants state difference in the color between the raisins of Type FW and those of Type RW.

H4: The participants state difference in the general appearance between the raisins of Type FW and those of Type RW.

H5: The participants state difference in the odor between the raisins of Type FW and those of Type RW.

H6: There is a difference in the willingness to buy for the raisins of the two designations.

H7: There is difference in the willingness to pay for the raisins of the two designations.

H8: There is a difference in the consumption between the two types of raisins.

\subsection{Results}

\subsubsection{Perceived difference between the different samples}

\subsubsection{H1: Difference in "liking" level between raisin "types"}

The responses given to the question "did you like the raisins you have tasted" are reported in Figure 2.2. According to Wilcoxon signed ranks test on the responses, H1 was confirmed; that is, participants were significantly more likely to state that they like more the raisins of Type FW compared to the raisins of Type RW $\left(Z_{W}=2.911, p=0.004\right)$ (recall that in fact both raisins "types" were in fact the same product).

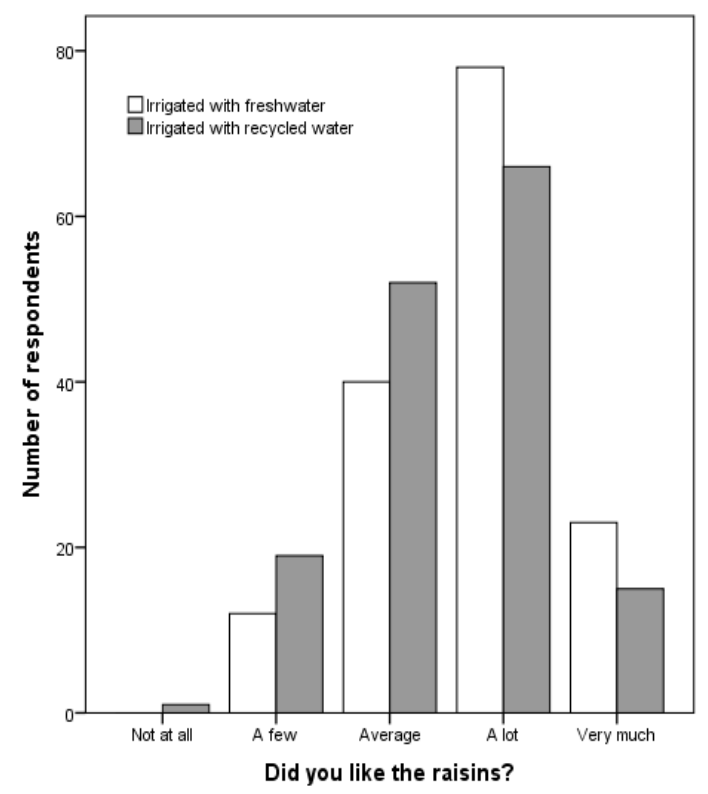

Figure 2.2: Difference in levels of "liking" the two types of raisins 


\subsubsection{H2-H5: Observed differences between the two raisin "types"}

A substantial majority of all participants (75.3\%) observed at least one difference between the raisins of the two "types." As shown in Figure 2.3, 66.1\% of all participants stated that the two samples have different tastes $\left(\chi^{2}=147.79, p<0.001\right)$, confirming H2, 20.9\% stated that the two samples have difference in the appearance $\left(\chi^{2}=33.539, p<0.001\right)$, confirming $\mathrm{H} 3$, and $14.3 \%$ of participants found a difference in the color $\left(\chi^{2}=21.598, p<0.001\right)$, confirming H4. A further $3.3 \%$ of participants stated that the two "types" of raisins smelled differently, but this observation was not statistically significant $\left(\chi^{2}=3.253, p=0.070\right)$ so H5 is not supported by the present findings.

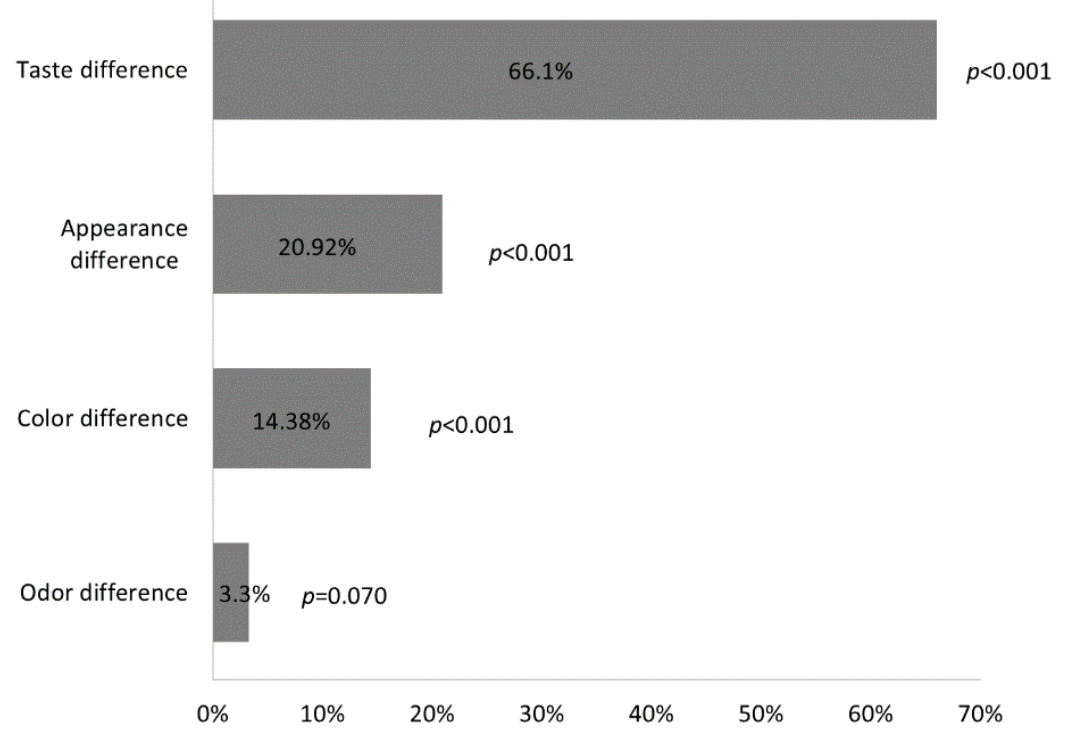

Figure 2.3: Percentage of observed difference between the two raisin "types"

\subsubsection{Stated willingness to purchase for the different samples}

Participants' responses on the questions "would you buy raisins irrigated with freshwater/recycled water" are reported in Figure 2.4. According to a Wilcoxon signed ranks test, the participants were more willing to buy raisins irrigated with freshwater (Type FW) than raisins labeled as irrigated with recycled water (Type RW) $\left(Z_{W}=3.957, p<0.001\right)$, supporting hypothesis H6. 


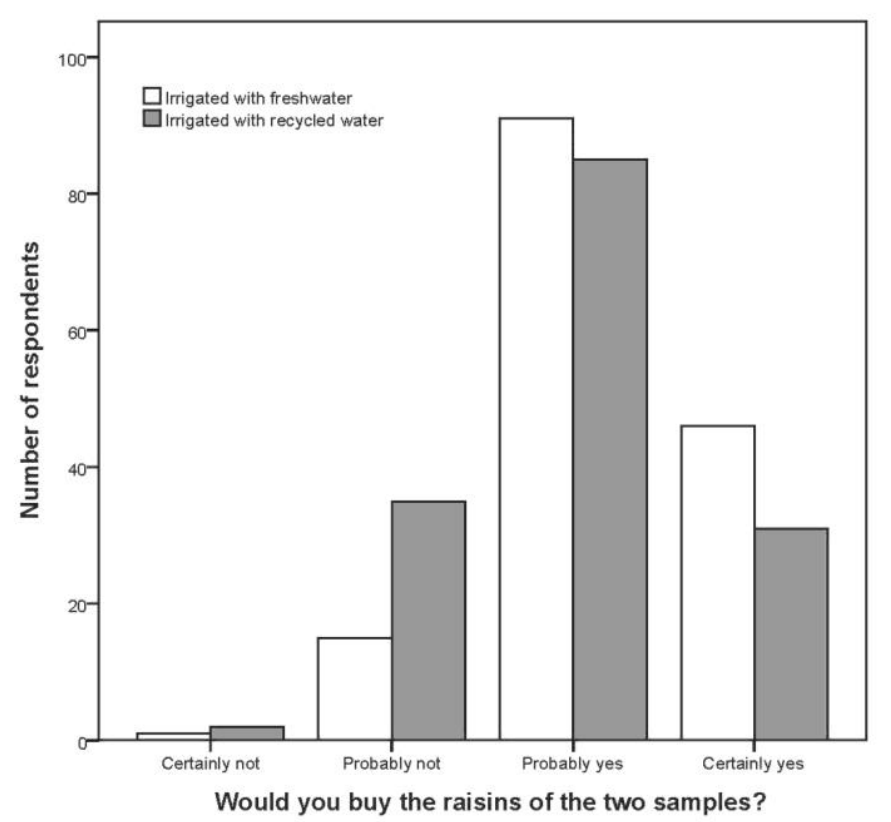

Figure 2.4: Willingness to buy the raisins of the two samples

\subsubsection{Willingness to pay for the two "types" of raisins}

The descriptive statistics of the responses given concerning the willingness to pay for Type FW and Type RW raisins are given in Table 2.1. Analyses from the complete dataset are presented in the first pair of columns, whereas the second pair presents the same analyses after filtering for extreme positive scores. The bids are not normally distributed (Kolmogorov - Smirnov test, $\mathrm{p}<0.001)$ and the follow two different distributions. The bids for Type FW follow the beta distribution while the ones of Type RW are randomly distributed as they do not fit to any of the known types of distribution. The WTP values of more than $0.90 €$ are excluded, $0.90 €$ is the max of mean WTP+St.Dev. For the two samples, with the upper WTP being the max $\{0.55+0.35 €, 0.57+0.21 €\}$. Note that for the unfiltered findings, no significant differences were observed in willingness to pay for the two "types" of raisins; indeed, despite the fact that a large majority of participants had reported some form of inferiority in the quality of RW raisins and overall were less willing to purchase this time, on average participants were willing to pay more for RW raisins (.55€) when FW raisins cost .50 cents.

Note, however, that the money the participants were willing to pay for purchasing raisins of Type RW with a FW anchor had a greater range $(3-0=3 €)$ compared to that for Type FW with a RW anchor $(2.00-0.25=1.75 €)$. There were participants who stated that they were unwilling to pay anything to buy raisins of Type RW (minimum amount in WTP for RW equals to zero) and others who were willing to pay five or six times the price of FW irrigated product (presumably individuals with high levels of environmental sensitivity). When extreme willingness to pay values are filtered, the WTP findings accord with the pattern of findings for the comparative quality (taste, appearance etc.) and the willingness to purchase data reported 
above; that is, the participants were less willing to pay for raisins of identical quality when they were said to be cultivated with recycled water $\left(Z_{W}=2.821, p=0.005\right)$.

Table 2.1: Descriptive statistics for willingness to pay for the two samples in Euros $(€)$

\begin{tabular}{lrrrr}
\hline & \multicolumn{2}{c}{ Unfiltered data } & \multicolumn{2}{c}{ Filtered for extreme scores } \\
\hline Statistics & $\begin{array}{r}\text { WTP for RW } \\
\text { (when FW } \\
\mathbf{0 . 5 0 € )}\end{array}$ & $\begin{array}{r}\text { WTP for FW } \\
\text { (when RW } \\
\mathbf{0 . 5 0 € )}\end{array}$ & $\begin{array}{r}\text { WTP for RW } \\
\text { (when FW } \\
\mathbf{0 . 5 0 € )}\end{array}$ & $\begin{array}{r}\text { WTP for FW } \\
\text { (when RW } \\
\mathbf{0 . 5 0 €} \text { ) }\end{array}$ \\
\hline $\mathrm{N}$ & 160 & 160 & 143 & 148 \\
\hline Mean & 0.55 & 0.57 & 0.46 & 0.53 \\
Std. Deviation & 0.35 & 0.21 & 0.14 & 0.12 \\
Mode & 0.50 & 0.50 & 0.50 & 0.50 \\
Minimum & 0.00 & 0.25 & 0.00 & 0.25 \\
25\% & & & & \\
Percentile & 0.40 & 0.50 & 0.40 & 0.50 \\
Median & 0.50 & 0.50 & 0.50 & 0.50 \\
75\% & & & & \\
Percentile & 0.60 & 0.60 & 0.50 & 0.60 \\
Maximum & 3.00 & 2.00 & 0.90 & 0.90 \\
\hline
\end{tabular}

Willingness to pay was clearly differentiated with respect to self-reported consumer satisfaction with raisins said to be cultivated with either fresh or recycled water. The "liking level difference" (LD) is operationally defined as the difference between the reported level of satisfaction or "liking" of Type FW and Type RW raisins (FW - RW = LD). A positive difference indicates that the participant liked more the raisins of Type FW; a negative difference indicates that the participants liked more the raisins of Type RW and a difference equal to zero indicates that the "liking" level of the two types was the same.

In Table 2.2, the results from the Wilcoxon test indicate that in the cases in which there is a non-zero difference in the "liking" level of the two types of raisins, there is a statistically significant difference in the willingness to pay. When this difference in "liking" level is equal to zero, then the difference in the willingness to pay was not statistically significant. Hypothesis 7 is thus confirmed in cases for which the "liking" level for FW and RW raisins was different.

Table 2.2: Liking level difference and willingness to pay

\begin{tabular}{|c|c|c|c|c|c|}
\hline Liking level & $\mathbf{N}$ & Median WTP & Type RW & $p$ value & $\mathbf{Z}_{\mathrm{W}}$ \\
\hline Difference & & Type FW & & & \\
\hline $\mathrm{LD}>0$ & 51 & 0.60 & 0.40 & 0.002 & 3.028 \\
\hline $\mathrm{LD}<0$ & 29 & 0.50 & 0.70 & 0.046 & 1.995 \\
\hline $\mathrm{LD}=0$ & 80 & 0.50 & 0.50 & 0.880 & 0.151 \\
\hline
\end{tabular}


Respondents who stated that liked more raisins of Type RW were willing to pay more for them compared to raisins of type FW. Respondents who stated that liked more raisins of Type FW were willing to pay more for them compared to raisins of type RW.

\subsubsection{Effect on the consumption}

According to Wilcoxon signed ranks test, no statistically significant differences were observed in consumption $\left(Z_{W}=0.998, p=0.318\right)$, so the $\mathrm{H} 8$ is rejected. Furthermore, 77 of the participants (50\%) consumed the same quantity of the two types, 49 of them $(31.7 \%)$ consumed more from the Type FW while 28 (18.2\%) consumed more from the Type RW.

\subsection{Discussion and Conclusions}

The present study aimed to investigate whether the designation of an edible agricultural product as derived from recycled vs. freshwater alters willingness to consume and the willingness to pay for the products, in accord with the so-called "yuck factor," that is, the disgust and rejection of objects known to have a history of contact with human waste. For this purpose we used identical products in two identical types of boxes, one denoted as "Irrigated with Recycled Water" and one "Irrigated with Pure Freshwater" and tested several hypotheses.

The descriptor "Irrigated with Recycled Water" clearly affected the perception of the participants in this experiment. A substantial majority of participants discerned nonexistent differences in the taste, color or appearance of the two "types" of raisins; overall, raisins thought to be derived from freshwater sources were preferred, and when extreme scores were filtered, willingness to pay was also higher for the putative "freshwater" product. These findings are significant because, although several studies have indicated that irrigation with recycled water has no impact on the quality of agricultural products if the appropriate technology has been employed for the treatment of wastewater (Christou et al., 2014; Battilani et al., 2014; Prazeres et al., 2014; Li et al., 2014), consumer acceptance appears likely to be determined by descriptions of the very recent history of the water molecules used for crop irrigation. Overall, the direction of this effect is in accordance with the so-called "yuck" factor, that is, the irrational belief that water is permanently contaminated by any contact with waste material, despite the fact that in the closed system of our planet's atmosphere, all water molecules will have contacted such material on a multitude of occasions. Furthermore, we found no statistically significant difference in the consumption level of the two types. We believe that respondents felt safe to consume raisins of type RW. However, it is probable that if we had put them to consume directly recycled water they would have observed difference in the consumption between the sample of fresh and recycled water. This work complements previous findings 
about suitable labeling (Mellon and Tsagarakis, 2006; Menegaki et al. 2007) and working for encouraging recycled water use (Tsagarakis et al. 2007).

A rather more surprising and encouraging outcome of the present experiment was the finding that the effect of the recycled water use designation on consumer's judgment of product quality and value was not universally in accordance with the so-called "yuck" factor. A minority of participants found the raisins said to be cultivated with recycled water to be of superior quality, and these participants were both more willing to use and to pay more for products merely because they were generated in a manner that preserves the naturally-purified water supply. These participants express a bias in the valuation of products cultivated with earthfriendly practices that would have to be described as a "yum" factor. This heartening individual variation in the effects of recycled edible product designations defines an important problem for applied behavioral science: how, precisely, do we get from "yuck" to "yum"? 


\section{References}

(ARCWIS), A. R. C. f. W. i. S. (2002). "Perth Domestic Water-Use Study Household Appliance Ownership and Community Attitudinal Analysis 1999-2000. CSIRO Urban Water Program, Sydney. ".

Anderson, J. (2003) The environmental benefits of water recycling and reuse. Vol. 3. Water Science and Technology: Water Supply (pp. 1-10).

Angelakis, A. N., Marecos Do Monte, M. H. F., Bontoux, L., \& Asano, T. (1999). The status of wastewater reuse practice in the Mediterranean basin: Need for guidelines. Water Research, 33(10), 2201-2217.

Bakopoulou, S., Polyzos, S., \& Kungolos, A. (2010). Investigation of farmers' willingness to pay for using recycled water for irrigation in Thessaly region, Greece. Desalination, 250(1), 329-334.

Battilani, A., Plauborg, F., Andersen, M. N., Forslund, A., Ensink, J., Dalsgaard, A., Solimando, D. (2014) Treated wastewater reuse on potato (solanum tuberosum). Vol. 1038. Acta Horticulturae (pp. 105-112).

Blumenthal, U. J., Mara, D. D., Peasey, A., Ruiz-Palacios, G., \& Stott, R. (2000). Guidelines for the microbiological quality of treated wastewater used in agriculture: Recommendations for revising WHO guidelines. Bulletin of the World Health Organization, 78(9), 1104-1116.

Christou, A., Maratheftis, G., Eliadou, E., Michael, C., Hapeshi, E., \& Fatta-Kassinos, D. (2014). Impact assessment of the reuse of two discrete treated wastewaters for the irrigation of tomato crop on the soil geochemical properties, fruit safety and crop productivity. Agriculture, Ecosystems and Environment, 192, 105-114. doi: 10.1016/j.agee.2014.04.007

Dupont, D. P. (2013). Water use restrictions or wastewater recycling? A Canadian willingness to pay study for reclaimed wastewater. Water Resources and Economics, 1(0), 61-74. doi: http://dx.doi.org/10.1016/j.wre.2013.03.002 
Genius, M., Manioudaki, M., Mokas, E., Pantagakis, E., Tampakakis, D., \& Tsagarakis, K. P. (2005) Estimation of willingness to pay for wastewater treatment. Vol. 5. Water Science and Technology: Water Supply (pp. 105-113).

Gerba, C. P., \& Rose, J. B. (2003) International guidelines for water recycling: Microbiological considerations. Vol. 3. Water Science and Technology: Water Supply (pp. 311-316).

Hurlimann, A. C. (2009). Water supply in regional Victoria Australia: A review of the water cartage industry and willingness to pay for recycled water. Resources, Conservation and Recycling, 53(5), 262-268.

Kaercher, J. D., Po, M. \& Nancarrow, B.E. (2003). Water Recycling Community Discussion Meeting I (Unpublished Manuscript). Perth: Australian Research Centre for Water in Society(ARCWIS). .

Klein, I., Strime, M., Fanderstain, L., \& Mani, Y. (2000). Irrigation and fertigation effects on phosphorous and potassium nutrition of wine grapes. Vitis, 39, 55-62.

Li, P. Y., Wu, J. H., Qian, H., \& Chen, J. (2014). Wastewater irrigation and associated risks to public health: A short review. Paper presented at the WIT Transactions on Biomedicine and Health.

Magesan, G. N., McLay, C. D. A., \& Lal, V. V. (1998). Nitrate leaching from a free-draining volcanic soil irrigated with municipal sewage effluent in New Zealand. Agriculture Ecosystems \& Environment, 70(2-3), 181-187. doi: 10.1016/s0167-8809(98)00150-9

Maurer, M. A., Davies, F. S., \& Graetz, D. A. (1995). Reclaimed Wastewater Irrigation and Fertilization of Mature 'Redblush' Grapefruit Trees on Spodosols in Florida. Journal of the American Society for Horticultural Science, 120(3), 394-402.

Mellon, R. C., \& Tsagarakis, K. P. (2006). Assessment of Implicit Meaning in the Design of Graphic Symbols for the Control of Recycled Water Use. Environment and Behavior, 38(5), 689-706. doi: 10.1177/0013916506287637

Menegaki, A. N., Hanley, N., \& Tsagarakis, K. P. (2007). The social acceptability and valuation of recycled water in Crete: A study of consumers' and farmers' attitudes. Ecological Economics, 62(1), 7-18. doi: 10.1016/j.ecolecon.2007.01.008 
Menegaki, A. N., Mellon, R. C., Vrentzou, A., Koumakis, G., \& Tsagarakis, K. P. (2009). What's in a name: Framing treated wastewater as recycled water increases willingness to use and willingness to pay. Journal of Economic Psychology, 30(3), 285-292. doi: 10.1016/j.joep.2008.08.007

Nancarrow, B. E., Leviston, Z., Po, M., Porter, N. B., \& Tucker, D. I. (2008) What drives communities' decisions and behaviours in the reuse of wastewater. Vol. 57. Water Science and Technology (pp. 485-491).

Paranychianakis, N. V., Nikolantonakis, M., Spanakis, Y., \& Angelakis, A. N. (2006). The effect of recycled water on the nutrient status of Soultanina grapevines grafted on different rootstocks. Agricultural water management, 81(1-2), 185-198.

Paranychianakis, N. V., Salgot, M., \& Angelakis, A. N. (2010). Irrigation with Recycled Water: Guidelines and Regulations Treated Wastewater in Agriculture: Use and Impacts on the Soil Environment and Crops (pp. 77-112).

Paranychianakis, N., Salgot, M., Snyder, S. A. \& Angelakis, A. (2015). Water Reuse in EUStates: Necessity for Uniform Criteria to Mitigate Human and Environmental Risks. Crit. Rev. Environ. Sci. Technol., 45:13, 1409-1468.

Po, M., Nancarrow, B. E., Leviston, Z., Porter, N., Syme, G. J., \& Kaercher, J. (2005). Predicting community behaviour in relation to wastewater reuse: What drives decisions to accept or reject? CSIRO Land and Water Perth, Australia.

Prazeres, A. R., Carvalho, F., Rivas, J., Patanita, M., \& Dôres, J. (2014). Reuse of pretreated cheese whey wastewater for industrial tomato production (Lycopersicon esculentum Mill.). Agricultural water management, 140, 87-95. doi: 10.1016/j.agwat.2014.04.002

Queensland Government (2008). Water quality guidelines for recycled water schemes: Department of Natural Resources and Water.

Salgot, M., Vergés, C., \& Angelakis, A. N. (2003) Risk assessment in wastewater recycling and reuse. Vol. 3. Water Science and Technology: Water Supply (pp. 301-309).

Tsagarakis, K. P., Dialynas, G., \& Angelakis, A. (2004). Water resources management in Crete (Greece) including water recycling and reuse and proposed quality criteria. Agricultural water management, 66(1), 35-47. 
Tsagarakis, K. P., \& Georgantzís, N. (2003) The role of information on farmers' willingness to use recycled water for irrigation. Vol. 3. Water Science and Technology: Water Supply (pp. 105-113).

Tsagarakis, K. P., Mellon, R. C., Stamataki, E., \& Kounalaki, E. (2007). Identification of recycled water with an empirically derived symbol increases its probability of use. Environmental Science and Technology, 41(20), 6901-6908.

Tziakis, I., Pachiadakis, I., Moraitakis, M., Xideas, K., Theologis, G., \& Tsagarakis, K. P. (2009). Valuing benefits from wastewater treatment and reuse using contingent valuation methodology. Desalination, 237(1-3), 117-125.

Water Corporation of Western Australia. (2003). Community Attitudes and Public Perceptions. Paper presented at the Water Recycling Workshop 25-26 June 2003, Perth, Australia.

World Health Organization (2006). Guidelines for the Safe Use of Wastewater, Excreta and Greywater: Policy and regulatory aspects (Vol. 1): World Health Organization.

\subsection{Appendix}

\section{Questionnaire}

\section{GENERAL QUESTIONS}

\section{Do you like eating raisins?}

Please choose only one from the following options

$\square$ Not at all $\square$ Somewhat $\square$ About average $\square$ A lot $\quad \square$ Very much

\section{Do you like the raisins that you have tasted from the first box?}

Please choose only one from the following options

$\square$ Not at all $\square$ Somewhat $\square$ About average $\square$ A lot $\square$ Very much

\section{Do you like the raisins that you have tasted from the second box?}

Please choose only one from the following options

$\square$ Not at all $\square$ Somewhat $\square$ About average $\square$ A lot $\square$ Very much

\section{Have you noticed a difference between the two samples?}

Check any that apply

There is no difference between the two samples 
There is a difference in their taste

There is a difference in the odor

There is a difference in the color

There is a difference in the appearance

5. How many times per month do you consume products which contain raisins?

\section{WILLINGNESS TO BUY AND WILLINGNESS TO PAY}

6 Would you buy raisins with similar quality to those contained in the first box?

Please choose only one from the following options

$\square$ Certainly no $\square$ Probably no $\square$ Probably yes $\square$ Certainly yes

7. Would you buy raisins with similar quality to those contained in the second box?

Please choose only one from the following options

$\square$ Certainly no $\square$ Probably no $\square$ Probably yes $\square$ Certainly yes

8. If this box of raisins with $50 \mathrm{~g}$ weight derived from grapes irrigated with freshwater costs $0,50 €$ how much would you be willing to pay to buy an identical box of raisins from grapes irrigated with recycled water certified for irrigation?

Please write your answer here:

9. If this box of raisins with $50 \mathrm{~g}$ weight derived from grapes irrigated with recycled water certified for irrigation costs $0,50 €$ how much would you be willing to pay to buy an identical box of raisins from grapes irrigated with clean water?

Please write your answer here:

PERSONAL DATA QUESTIONS

10. Gender $\quad \square$ Male $\quad \square$ Female

11. Age

12 Which is your monthly income?

Please choose only one from the following options
$\square<500 €$
500-700€
$700-1000 €$
$>1000 €$ 
DATA FILLED IN BY THE EXPERIMENTER

Quantity of raisins consumed from the first box:

Grams before the consumption.

Grams after the consumption

Quantity of raisins consumed from the second box:

Grams before the consumption

Grams after the consumption 


\title{
3. A comparative assessment of the Willingness to Pay between Organic and Conventional Products. Case Study: Table olives
}

\begin{abstract}
The present paper provides further insight on the consumers' behavior by testing the effect of the descriptor "organic product" on the willingness to pay for agricultural products. First, following usual practices in marketing research, we acquire information on participants' stated willingness to pay (WTP) for this descriptor (hypothetical part). Additionally, the same person participated in a real reward experiment designed to replicate the scenario valued in the hypothetical part. Our results show that regardless of the presence of the descriptor "organic" there is no statistically significant difference between the hypothetical and the real WTP, and that the revealed preferences are adequately predicted by the declared ones.
\end{abstract}

Keywords: Consumer preferences; Experimental economics; Experimental preferences; Hypothetical preferences; Organic products; Willingness to pay

\subsection{Introduction}

The ongoing environmental awareness of the past two decades, combined with concerns about the quality of the products and the demand for safer food have led consumers to question modern agricultural practices. It has been found, that consumers consider the perceivable characteristics of food, such as appearance and taste, to be the most crucial factors in their choice of food (Magnusson et al., 2001). However, there is strong evidence that other not so easily tangible food attributes e.g. their quality and production process are becoming increasingly important (Torjusen et al., 2001). This new way of thinking led to an increase in the demand of organic produced agricultural products, which are perceived to be less damaging to the environment and healthier than conventionally grown ones (Schifferstein \& Oude Ophuis, 1998; Williams \& Hammit, 2001).

Commonly, the products labeled as organic are promoted as being of higher quality and nutritional value, consequently creating a positive public opinion. Studies have shown that organic products are considered, by many consumers, to be superior solely based on criteria needed for organic production, such as the use of natural raw materials (Midmore et al., 2005; Saba \& Messina, 2003). Moreover, in many studies, public concern on health issues appeared to be the main reason for buying organic food (Carboni, Vassallo, Conforti, \& D'Amicis, 2000; Tregear, Dent, \& McGregor, 1994). This public concern is part of a widespread unrest among 
consumers about the quality of food we consume even though there is no unambiguous evidence that organic food is healthier than conventional (Torjusen, et al., 1999).

In many instances, consumers seem willing to pay more money in order to buy products, especially fruit and vegetables, which are toxic-free and beneficial to their health (e.g. Tranter et al., 2009; Batte et al., 2007; Magnusson et al., 2003; Mc Eachern et al., 2005). In the literature several researches have been conducted focusing specifically on the determination of the consumers' willingness to pay (WTP) for specific characteristics of goods (i.e. Combris et al., 2002). Most of these studies, based on a hypothetical scenario, aimed to provide evidence on how the quality signs influence the perceived quality of the product but fail to put the consumers under a real dilemma through which their real willingness to pay for these products can be observed. But what happens when the consumers are confronted with the true prices of such products? Do they actually buy them or does their stated willingness to pay differ from their real one?

A general bias towards willingness to pay (WTP) elicitation methods for organic products, or for products which are labeled as "green" or "ecological" is, that consumers tend to show an innate preference for them. On the other hand, this attitude is, most of the times, overrated and evoked by the, so called, environmental awareness. It has often been argued that when a clear and controlled motivation, aiming to reveal individuals' true preference is absent, they may indicate higher WTP because such an attitude is considered to be politically correct (Camacho-Cuena et al., 2003 and 2004). As Nyborg (2000) points out, inexpensive statements regarding the willingness to pay in order to buy something can cause consumers to behave as "homo politicus". Conversely, at times when contributions have a real cost, consumers would behave as "homo economicus".

The aim of the current research is to detect potential differences in the WTP between the Declared Willingness to Pay (DWTP) and the Real Willingness to Pay (RWTP) in a dichotomous choice experiment, setting participants to select between an organic and a conventional product of the same type. Technically, this experiment resembles a voting mechanism between two products. In such a voting mechanism what is required, except for the restriction to just two alternatives, is the assumption that individuals perceive their utilities to be affected by the outcome of the vote. Consequently, the understanding that their behavior will have a real effect on their utility causes the participants to act responsibly and vote honestly; ergo, the participants in the hypothetical part are indifferent toward their choices because there will be no impact on their utility. On the contrary, in the real part, the voting will affect their utility by affecting their real earnings. In similar experiments conducted by Camacho-Cuena et al. (2003 and 2004), no statistically significant difference was found between the declared and 
the real WTP in a dichotomous choice experiment. Moreover, the "epsilon truthfulness" assumption (Cummings et al., 1997), which supports the view that participants will behave the same in the hypothetical part as they would in the real one, is put to question.

The innovation of this research is that it is the first to experimentally validate survey data on WTP for a single environmental attribute of a market product when the descriptor "organic" is used, in order to define the origination of it. Along with comparisons of the consumers' inclination for organic products, our within-participants design aims to compare stated and real WTP at an individual level. In this context, each participant's stated WTP in the hypothetical part is compared to his/her real WTP drawn out in an experimental session, designed to be both economically feasible and appropriate for replicating a real world choice situation in a lab.

\subsection{Research Methodology}

Consider a model of vertical production line with two identical products differing only in a single attribute: the conditions of their production process. Products are labeled "conventional" and "organic" depending on the production methods employed, as designated by the current legislation.

Consumers may have a positive consideration towards the organic origin of a product. In such a case, the indirect utility function of a consumer purchasing one unit of the conventional products is:

$$
U_{c}=R-P_{c}
$$

Whereas, the purchase of a unit of the organic one implies a utility:

$$
U_{o}=R+W_{i}-P_{o}
$$

$R$ represents the consumer's reservation price which, in other words, is the highest price that a consumer is willing to pay in order to buy the product, $P_{c}$ the price of the conventional product, $P_{o}$ the price of the organic product, and $W_{i}$ consumer $i$ 's WTP for the organic product's additional characteristics which create a "superior quality" predisposition.

Consumers will grow more inclined toward the organic product to the conventional only if $U_{o}>U_{c}$, which implies that the following holds:

$$
W_{i}>P_{o}-P_{c}
$$

The Equation (3) signifies that consumers buy the organic product only if their WTP for the characteristics of the organic product offsets the price difference across products. 


\subsection{Product Description}

The selected product for the experiment was green olives from the variety of Chalkidiki and of "Super Colossal" size, corresponding to 120 olives per kilogram, packaged in plastic packs suitable for food storage. The net weight of the final product was $450 \mathrm{gr}$ and the average retail price in the markets was about $1.80 €$. The reason for selecting this product was the fact that it is widespread in the market and is a widely consumed product. It is available in stores in various micro-packaging types, such as glass jars and plastic packs which are produced in numerous sizes with different net product weights. Therefore, taking into account the variety of prices of similar products in the market, the knowledge of the accurate selling price of the specific product by the participants was almost impossible.

Moreover, it is noteworthy to say that olive products are perceived to be products of high nutritional value and therefore, many consumers prefer to buy the organic from the conventional ones which are used in the Mediterranean diet in a daily basis. Olives, fruit and vegetables are some of the few organic products of Greek origin which can be easily found in the Greek market and the organic products consumers have high preference to them (Krystallis et al., 2006). To that end, our product embraces a notable share of the market.

\subsubsection{Label Design}

In order to comply with the standards of the professional, two different labels were designed and created by a publishing firm in line with the international standards on professional packaging. In other words, a typical exportable package of olives was created along with two different labels to indicate that the first package contained olives of conventional farming while the second one contained olives of organic farming.

The product's brand name was chosen after a thorough market research and a new brand name was invented along with a unique logo. The brand name "Greek Olive Grove" was assigned to the product since no other product existed with that brand name or a similar one and because it describes it in a clear manner. It was not translated into Greek and was the same on both packages, since the majority of similar products available in the international and in the Greek market have titles either in English or their titles are written with Latin characters to reflect its Greek name. The image, which was chosen to accompany the title, is a colored image of olive trees of Chalkidiki region. The label contained information concerning the expiration date, the content, the net weight of the product, and the country of origin accompanied by a Greek flag. At the bottom, a barcode and a traceability code (Lot Number) were inserted, elements which are essential for products that are in the production line. 
The key elements that differentiated the two labels were the product description, their barcodes, their ingredients and their certification logos. The first product, the conventional olives of Chalkidiki was described as "Green Olives of Chalkidiki in Brine" while the second one, the organic olives of Chalkidiki was described as "Organic Green Olives of Chalkidiki in Brine" in both Greek and English. Both products also had a certification mark, which is compulsory for all the exported products (EuroCert). Additionally, the European label for organic products was inserted onto the alleged organic product. The EU quality label for organic products gets a product easily accepted by consumers and thus is a good marketing strategy but it is also necessary to the extent of differentiation between the two products (Krystallis et al., 2006). The mark was placed according to the specifications of the official labeling rules as they are posted on the European Union page for organic products (European Commission European Commission Agriculture and Rural Development, 2010 and 2015).
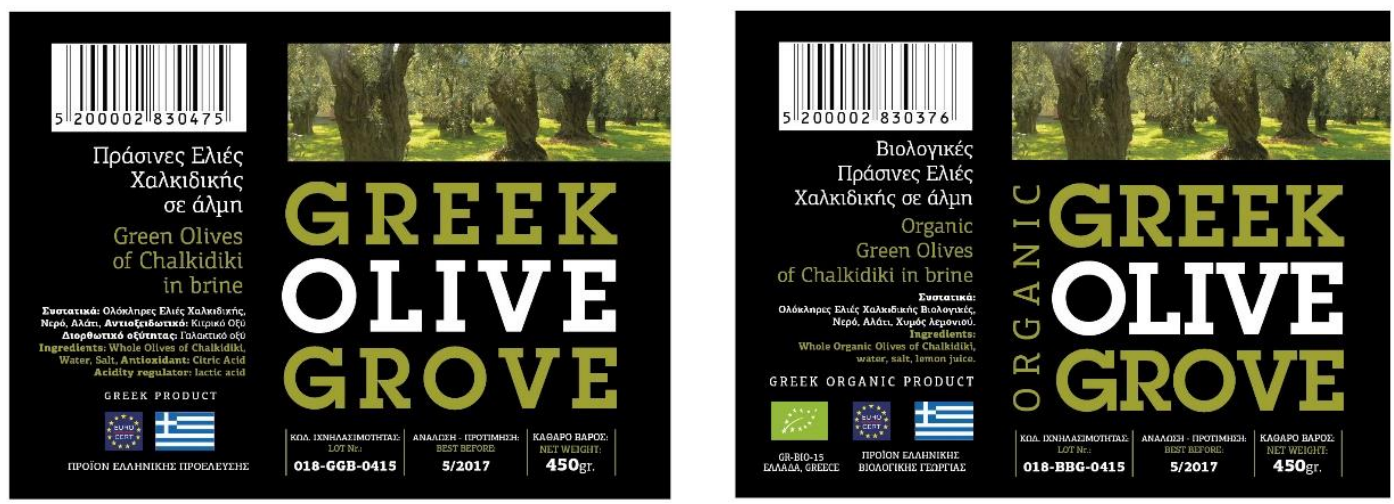

Figure 3.1 The labels of the two products

In our experiment, the aforementioned samples of table olives were used. The information that the participants had was that the only difference between them lies in the contents of each sample; one sample contained organic table olives while the other one contained conventional ones. This difference appeared on the ingredients written on the labels of each product (Figure 3.1). In fact both samples contained conventional olives preserved in brine, so that there is no difference in their general appearance. Each session was implemented on three successive phases during which no communication was permitted among the participants as depicted in Figure 3.2. 


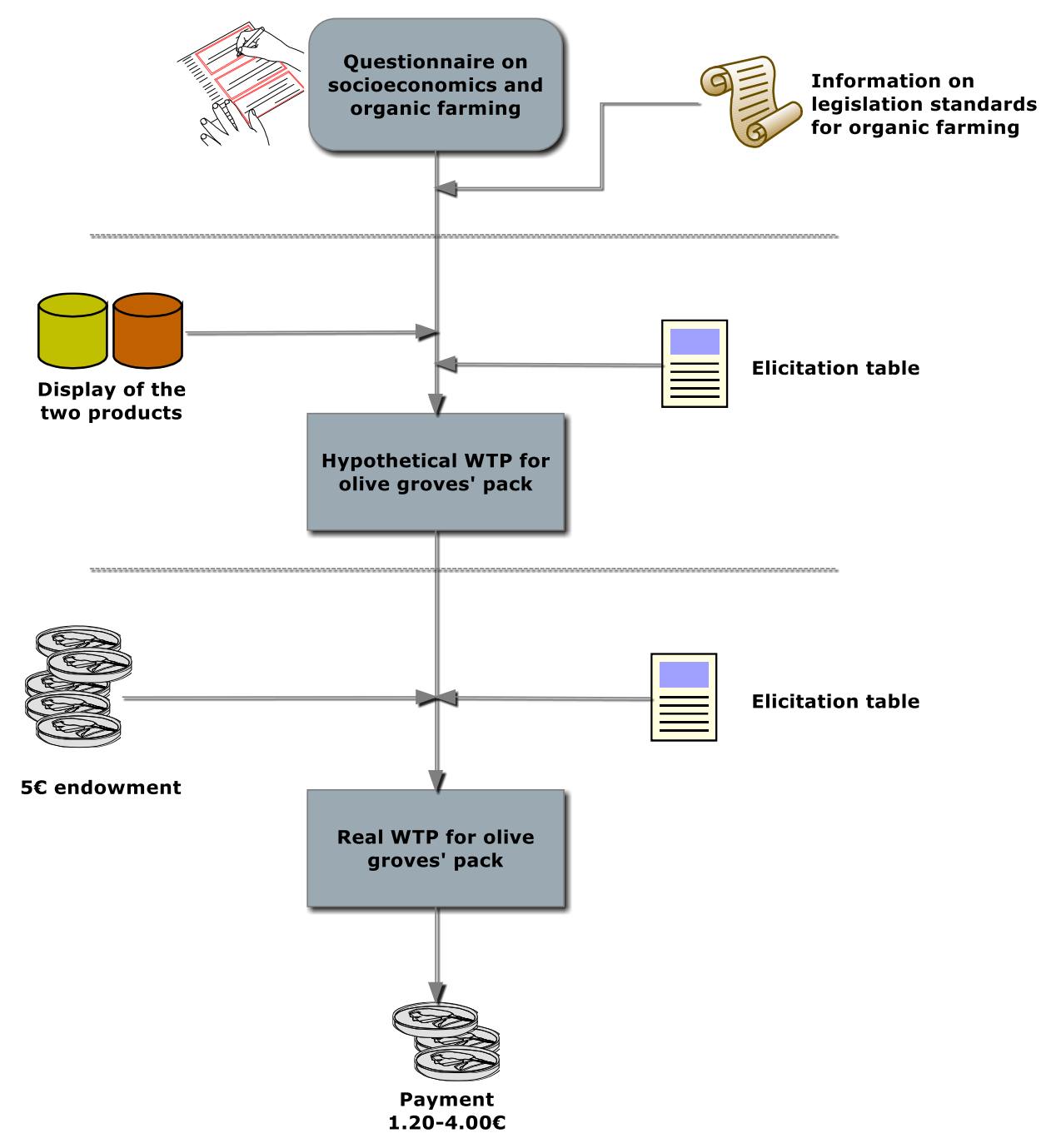

Stage 1

Stage 2

Stage 3

Figure 3.2 Structure of the experiment

\subsection{Experiment}

In order to reassure that the thermal and comfort conditions were the same for all the participants, the experiment was carried out in the Business Economics and Environmental Technology (BETECO) laboratory in the Environmental Engineering Department of the Engineering School of the Democritus University of Thrace (Greece). The participants were 89 university students from different academic years and faculties of the Engineering School, selected randomly so as to avoid the recirculation and the diffusion of the details of the experiment. After entering the laboratory, the participants were instructed to fill in a brief questionnaire (see Appendix). The questionnaire was divided into three parts, each one corresponding to the three stages of the experiment. 


\section{Stage 1: Introductory stage}

In the first implemented stage, the initial part of the questionnaire (Questionnaire part I) was given to the participants and they were instructed to answer eight general questions regarding their perception on environmental and organic product issues, their eating habits of these products, and finally, some demographic questions.

The goal of this part of the questionnaire was to create an environmental and behavioral profile for each one of the participants in order to determine the connection between the consumers' attitude towards the environmental issues and their willingness to pay for "green products" (Laroche et al., 2001). Moreover, this part included one question requesting the perceived knowledge of English language since the brand name of the product was in written in English. After the participants responded to all the questions, the experimenter collected the questionnaires before the second stage of the experiment commenced.

\section{Stage 2: Hypothetical WTP part}

At this stage, the two packages were presented to the participants along with instructions and a description of the existing legislation on the production of organic farming products (Questionnaire part II).

The validity of the responses to the hypothetical question "If you were given a pair of prices (Pc, Po), which package of table olives would you buy?" was tested using a withinparticipants experiment. In this context, they were instructed to respond to a series of pricescenarios. A table of fifteen (15) different pairs of price-scenarios was given to them and they had to choose for each price-scenario which one of the two products they were willing to buy. It was decided that the participants were given the opportunity to make repeated choices because by allowing them to practice, they had the opportunity to refine their responses into a more accurate reflection of the price at which they value the product (for more on this set up see Morisson, 1998). Moreover, this design helps us widen and expand the findings of previous researches in which the participants were faced with only one price scenario (Cummings et al., 1995) while at the same time facilitate the collection of more detailed information on each participant's WTP. Furthermore, this design is appropriate so as to evade problems associated with a fully open question. This elicitation method establishes the context in which the bids should be submitted while avoiding starting point bias. Additionally, the number of outliers is also reduced in comparison to open-ended and dichotomous choice formats. 
In each scenario, the organic olives' price takes a different value ranging from below to quite above the conventional products' price. The latter price keeps in line with the price in which the product was actually sold in the retail market. Table 3.1 presents the elicitation question format. In the experiment, this question becomes "Which olives would you buy?"

Table 3.1 Format of the specific question of the Questionnaire Part II.

\begin{tabular}{ccc}
\hline Scenario & $\begin{array}{c}\text { Conventional } \\
\text { Olives' price (Pc) }\end{array}$ & $\begin{array}{c}\text { Organic Olives' } \\
\text { price }\end{array}$ \\
\hline (Po)
\end{tabular}

After the participants were done answering the questionnaire, the experimenters collected the answer sheets. Participants did not receive any information concerning the next parts of the session, nor could they assume that their behavior in this part of the experiment could be individually compared to their decisions in the following parts. This element was further supported by the fact that the whole session was conducted anonymously. Participants had no knowledge of the results obtained from this part before proceeding to the next one.

\section{Stage 3: Real WTP part}

In the real WTP part of the session, the participants were given the instructions together with a leaflet describing the characteristics of the olives, the legislation (in the exact same way as in the hypothetical part of the session), and the price-scenarios table (Questionnaire Part III). In addition to that, they were given an endowment of $5 €$ part of which, as they have been instructed, should be spent to buy one of the two table olives available. At the end of this 
procedure, a lottery (in which each one of the fifteen scenarios was equally likely to be chosen) was conducted for each participant in the interest of indicating the scenario that would determine his/her payment. The participants' actual earnings depended on the strategy chosen in the scenario randomly selected by the lottery. Their payment was the difference between their initial endowment $(5 €)$ and the price corresponding to the product they had previously chosen (Stage 3) to buy for the scenario selected by the lottery (e.g. 5.00-1.60=3.40€, if organic olives were selected in scenario 4). The payment was made after the end of this stage and the participants also received the product of their choice in the selected scenario.

Following the accomplishment of this stage, the decision tables were handed out to the experimenter.

The goal of these two sessions (Stage 2 and Stage 3) was to track down potential differences between the participants' declared willingness to pay (DWTP) for the two products in the hypothetical part (Stage 2) and their real willingness to pay (RWTP) for those products in the real part (Stage 3). Based on this, our research hypothesis is formulated.

\section{H1: There is a difference between the declared willingness to pay (DWTP) and the} real willingness to pay (RWTP) for organic olives.

By all means, such a design is not appropriate for assessing the importance of possible ordering effects. Such effects, however, were not proven significant. A further source of strong ordering effects may be the time schedule of the experiment that asked the participants to reply to the hypothetical and to the real part in limited time. It is true that in order to reach safe conclusions about the results of this research, the current data should be compared to experiments conducted principally under real conditions or to ones that have been conducted over a longer time span. Keeping this in mind, the current experiment does not aim to be regarded as a general method for validating stated preferences in survey questions but has a purpose to investigate human behavior under a certain economic scenario.

\subsection{Results}

In this section, the results obtained from the experiment are presented. It consists of general findings, WTP intra-stages analysis, and WTP analysis. In the post-session analysis of the responses, a small number of participants (3 out of 89) seem to have followed totally random and irrational patterns of choice. Thus, their behavior is excluded from any further data analysis. 


\subsubsection{Introductory questions and Descriptive statistics}

In Table 3.2, there is a presentation of the data collected from the answers to the questions concerning respondents' perception on environmental and organic products issues and their consumption habits of these products. The vast majority of the participants declared that they consider the environmental issues to be very important (62.9\%) and important (32.6\%). Nonetheless, these findings are not implying that the participants are informed about the procedure of the production of organic agriculture products since $44.2 \%$ of them stated that they are a little informed and $20.9 \%$ that they are neither informed, nor uninformed. Finally, it is clear that most of the individuals participating in the current experiment are not frequent buyers of organic products considering $30.2 \%$ of them buy such products scarcely and $48.8 \%$ buy them some times.

Table 3.2 Responses given to the introductory questions

\begin{tabular}{|c|c|c|c|c|c|}
\hline \multicolumn{2}{|c|}{$\begin{array}{l}\text { Participants' declared } \\
\text { importance of environmental } \\
\text { issues }\end{array}$} & \multicolumn{2}{|c|}{$\begin{array}{l}\text { Participants' information level } \\
\text { on the procedure of the } \\
\text { production of organic } \\
\text { agricultural products }\end{array}$} & \multicolumn{2}{|c|}{$\begin{array}{l}\text { Participants } \\
\text { frequency of } \\
\text { purchasing organic } \\
\text { products }\end{array}$} \\
\hline Unimportant & $1.2 \%$ & Not informed & $9.3 \%$ & Never & $7.0 \%$ \\
\hline $\begin{array}{l}\text { Relatively } \\
\text { unimportant }\end{array}$ & $1.2 \%$ & A little informed & $44.2 \%$ & Scarcely & $30.2 \%$ \\
\hline $\begin{array}{l}\text { Neither important, } \\
\text { nor unimportant }\end{array}$ & $2.3 \%$ & $\begin{array}{l}\text { Neither informed, } \\
\text { nor uninformed }\end{array}$ & $20.9 \%$ & Some times & $48.8 \%$ \\
\hline Important & $32.6 \%$ & Informed & $22.1 \%$ & Frequently & $12.8 \%$ \\
\hline Very important & $62.9 \%$ & Very informed & $3.5 \%$ & Always & $1.2 \%$ \\
\hline
\end{tabular}

\subsubsection{Socioeconomics and organic farming questions' analysis}

The analysis of the responses given to the first stage of the experiment provided some insights about our sample which are summarized as follows. First off, the more informed the participants were on the procedure of the production of the organic products, the more probable they were to buy them with more frequency $\left(r_{s}=0.294, p=0.006\right)$. Along with that, participants with higher stated frequency of purchasing organic products were willing to spend more money to buy them in both the hypothetical $\left(r_{s}=0.376, p<0.001\right)$ and the real part $\left(r_{s}=0.321, p=0.003\right)$. Additionally, participants who are members of associations for the protection of the natural environment stated to be more informed on the procedure of the production of organic products $\left(\mathrm{U}_{\mathrm{M}-\mathrm{w}}=49.5, p=0.013\right)$ and purchase them more frequently $\left(\mathrm{U}_{\mathrm{M}-\mathrm{w}}=71, p=0.039\right)$ than those who do not belong in such associations. 
Furthermore, a gender effect exists concerning the sensitivity of environmental issues and the frequency of buying organic products. The female participants of the experiment were found to consider environmental issues more important $\left(\mathrm{U}_{\mathrm{M}-\mathrm{w}}=707.5 p=0.030\right)$ and buy organic products more frequently $\left(\mathrm{U}_{\mathrm{M}-\mathrm{W}}=705, p=0.044\right)$ than men.

\subsubsection{WTP intra-stages analysis and descriptive statistics}

The Table 3.3 presents the percentage of participants purchasing the organic olives according to their responses in the hypothetical and the real part in the experiment.

Table 3.3 Percentage of responses for Willingness to buy for the organic olives for each one of the fifteen scenarios.

\begin{tabular}{llll}
\hline Price (in $€)$ & $\begin{array}{l}\text { DWTB (\%) } \\
\text { (Hypothetical part) }\end{array}$ & $\begin{array}{l}\text { RWTB (\%) } \\
(\text { Real part) }\end{array}$ & $\begin{array}{l}\text { Difference } \\
(\%)\end{array}$ \\
\hline 1.00 & 98.84 & 98.84 & 0.00 \\
1.20 & 98.84 & 98.84 & 0.00 \\
1.40 & 100.00 & 100.00 & 0.00 \\
1.60 & 100.00 & 100.00 & 0.00 \\
1.80 & 95.35 & 95.35 & 0.00 \\
2.00 & 90.70 & 87.21 & 3.49 \\
2.20 & 81.40 & 76.74 & 4.65 \\
2.40 & 66.28 & 62.79 & 3.49 \\
2.60 & 53.49 & 56.98 & -3.49 \\
2.80 & 44.19 & 43.02 & 1.16 \\
3.00 & 27.91 & 33.72 & -5.81 \\
3.20 & 19.77 & 22.09 & -2.33 \\
3.40 & 12.79 & 18.60 & -5.81 \\
3.60 & 11.63 & 17.44 & -5.81 \\
3.80 & 10.47 & 15.12 & -4.65 \\
\hline
\end{tabular}

Observe that, when the price of the organic olives is equal to or lower than that of the standard olives (1.80€), almost all the subjects prefer to buy the organic olives. This fact proves the existence of a vertical differentiation aspect regarding the way in which the two products are perceived by consumers, introduced by the labeling of a product as organic. The gradual increase of the price of the organic olives lowers, as expected, the percentage of consumers who prefer to buy it instead of the standard one. This data is confirmed in both the hypothetical and the real part of the experiment. 
A Kolmogorov-Smirnov test was used so as to verify that the DWTP and RWTP are not normally distributed ( $p=0.010$ for DWTP and $p=0.002$ for RWTP). Therefore, nonparametric tests are used to check for intra-treatment differences (all tests are performed at 5\% level of significance).

After performing a two-tailed Wilcoxon test, it was discovered that the differences in the willingness to buy between the two stages are not statistically significant $(p=0.868)$. Moreover, as shown in Figure 3.3, the willingness to buy (WTB) organic products is equal to that of conventional products at the price of $2.6 €$ in both the hypothetical and the real part.

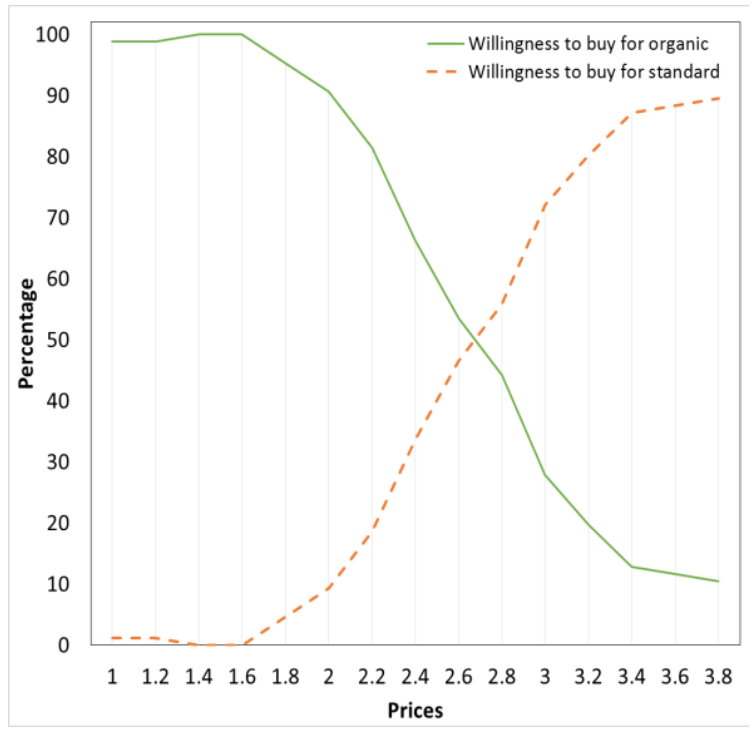

(a)

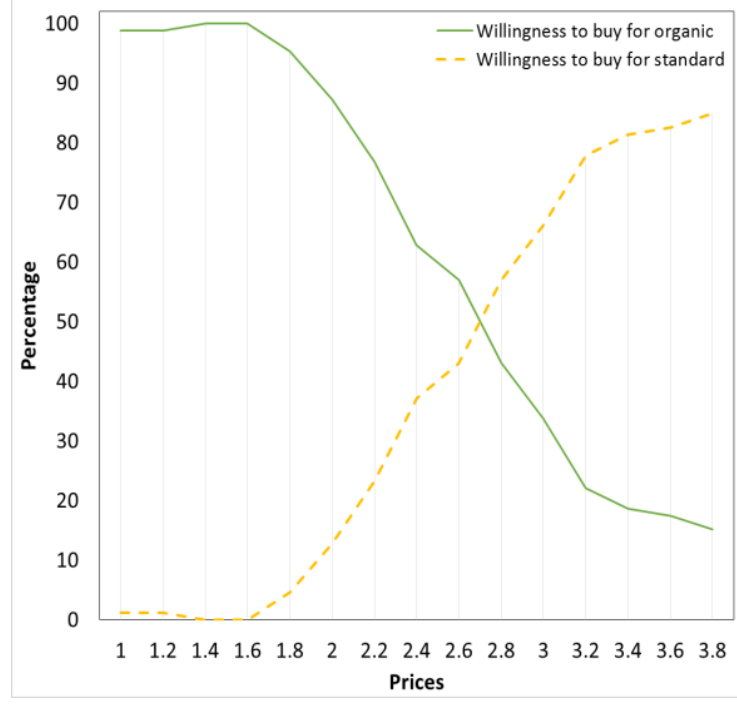

(b)

Figure 3.3 Willingness to buy for the organic and conventional olives for the fifteen price scenarios in the hypothetical (a) and in real part (b)

Furthermore, from straightforward calculations of the data presented in Table 3.3, we realize that the optimal price for a firm selling the organic olives is $2 €$ since, at this price, the profit $\pi\left(\pi=\right.$ Price $\left.^{*} \mathrm{WTB}\right)$ in both hypothetical and real part is maximized.

In Table 3.4 we present the descriptive statistics on the declared (in the hypothetical part) and the revealed (in the real part) WTP of the organic olives denoted as DWTP and RWTP respectively. 
Table 3.4 Descriptive statistics of the declared and revealed WTP

\begin{tabular}{lrr}
\hline Statistics & \multicolumn{1}{c}{ DWTP } & RWTP \\
\hline Minimum & 1.600 & 1.600 \\
$25 \%$ & & \\
Percentile & 2.200 & 2.200 \\
Median & 2.600 & 2.600 \\
$75 \%$ & & \\
Percentile & 3.000 & 3.000 \\
Maximum & 3.800 & 3.800 \\
Mode & 2.800 & 2.600 \\
Mean & 2.626 & 2.660 \\
Std. Deviation & 0.600 & 0.667 \\
\hline
\end{tabular}

It should be noted that the mean value of the RWTP is slightly higher than the one of the DWTP but the median value is the same for both variables. Regarding the spread of the responses, we see a higher dispersion in the data collected in the real part as compared to those in the hypothetical part (the statistical significance of the differences with non-parametric tests is discussed below).

Overall, in both the hypothetical and the real part of the experiment, the participants behave in a totally consistent way with their declared preferences $\left(r_{s}=0.383, p<0.001\right.$ and $r_{s}=0.334, p=0.002$ respectively) on buying organic agricultural products (Questionnaire, part I). In addition to that, even though there is no indication in the hypothetical part that the participants' awareness level on the procedures of production of the organic products affects the WTP for them $\left(r_{s}=0.154, p=0.157\right)$, in the real part such an indication exists and is statistically significant $\left(r_{s}=0.249, p=0.021\right)$.

The main result of our analysis can be obtained from a Wilcoxon paired rank test: there is no statistically significant difference between WTP in the hypothetical part and WTP in the real part $(p=0.673)$. Therefore $H_{l}$ is rejected.

The scheduling of the decision making that each participant has to cope with (first, the answer to the hypothetical and then the real part) and our interest in the value of the hypothetical part as a reliable predictor of future actions, justifies the need to identify the degree to which a participant's RWTP could reliably be predicted by his DWTP. That is, if the participants' declared willingness to pay in the hypothetical scenario reflected their actions in the real one.

In an attempt to test this hypothesis we regress participants' RWTP over DWTP. 
Table 3.5 RWTP estimation results for organic olives

\begin{tabular}{lcr}
\hline Statistics & \multicolumn{2}{c}{ Model } \\
\cline { 2 - 3 } V & $\widehat{\boldsymbol{\beta}}$ & $\boldsymbol{t}$-statistic \\
\hline $\mathrm{C}$ & 0.230 & 1.272 \\
DWTP & 0.926 & 13.781 \\
$\mathrm{R}^{2}$ & & 0.693 \\
\hline
\end{tabular}

It is worth noticing that DWTP is significant at $1 \%$ significance level $(p<0.001)$. As shown in Table 3.5, there is a positive correlation between the RWTP and the DWTP which means that a unit increase in the declared WTP will cause an increase in the real one. From the $\mathrm{R}^{2}$ we see that the DWTP in our model predicts the RWTP at level of $69.3 \%$.

\subsection{Discussion}

Divergence was observed in the participants' responses regarding their preferences in organic products and the additional amount they intend to pay in order to purchase them. In the literature a similar differentiation is observed among consumers and the premium price that they are willing to pay varies (Krystallis et al., 2006). This diversity in preferences has also been investigated in depth and is often explained by the difficulty the consumers have when they have to make logical choices in complex purchasing conditions (Hjelmar, 2010). This lack of a rational way of thinking often leads them to unsound judgment and they act based on their habits. As several researches have shown (i.e. Lodziak, 2002; Wood \& Neal 2009), many consumer activities are formed on daily routines.

Furthermore, the observed difficulty of a decision can be presumed that derives from conflicting attitudes towards organic and, in general, towards green products. A survey conducted by Laroche et al. (2001) stated that the fact that an increasing number of people willing to pay more for green products is, perhaps, the most convincing evidence that supports the development of an ecologically favorable consumer behavior. Yet, there are several reasons responsible for an unfavorable attitude towards organic products. These are, primarily, the perception of their high price and their low availability, the lack of trust in the biological signal and the general misunderstanding of organic production (Zotos et al., 1999; Chryssochoidis, 2000; Fotopoulos \& Krystallis, 2002a, 2002b).

Moreover, experiments and surveys have two distinctive features compared to real markets: limited time and limited knowledge. While in a real market a consumer may take time to gather information about the product before making his/her decision, a respondent in an experiment or survey has to report or act upon a WTP value which is provided by the researcher 
during the experiment or survey.

Regarding the socio-demographic profiles of consumers of organic products they are mostly female, who buy larger quantities and more often than men. This statement is consistent with the results of our study in which female participants consider environmental issues more vital and buy organic products more frequently (e.g. Tregear et al., 1994; Grunert \& Juhl, 1995; Davies et al., 1995; Reicks et al, 1997; Latacz-Lohmann \& Foster, 1997; Govindasamy \& Italia, 1999; Ureña et al., 2008).

According to Laroche et al. (2001) the consumers' attitude towards the environment is a very good indicator of their WTP for green products. This opinion, though, contradicts the results of our research. Despite the fact that $95.5 \%$ of the respondents answered "very important" and "important", when asked about how important they consider the environmental issues to be, this statement surprisingly shows no correlation to their WTP for those products neither in the hypothetical nor in the real part of the experiment. This conclusion is also supported by Vlosky et al. (1999) who report that consumers are split regarding the level of their environmental awareness and their willingness to choose more expensive environmentally oriented products.

Furthermore according to Krystallis et al. (2006), Greek consumers are more familiar with the idea of paying more to purchase fresh organic products; hence the WTP for these products reflects the real and not merely their hypothetical behavior. This statement is in line with the results of our research as in both the hypothetical and the real part of the experiment, the participants behave consistently with their stated preferences in the questionnaire and their responses in those parts, in average, show no deviation. These results go along with findings from Camacho-Cuena et al. (2003) who report no difference between the declared and the real willingness to pay, in a similar experiment. In the cases in which the participants stated a WTP that was significantly higher from the average, they behaved in consistent ways with their selections in the real part they revealed similarly high WTP.

\subsection{Conclusion}

The current study aimed to investigate whether difference between the declared and the real willingness to pay (WTP) exists in agricultural products when the descriptor "organic" is used, in order to define the origination of one of them. In order to achieve that, we run a dichotomous choice experiment, setting participants to select between an organic and a conventional product of the same type. For that reason, two products under the label "Organic Green Olives of Chalkidiki in Brine" and "Green Olives of Chalkidiki in Brine" were used. In the hypothetical 
part of the experiment the participants declared their preference and their WTP for each one of the two products while in the real part, a payment in cash was implemented along with the possibility of being rewarded with the product valued.

Despite the fact that a diversity was observed in the participants' answers regarding their preferences in organic products and the additional amount they intend to pay in order to purchase them, no significant difference was found between their DWTP and their RWTP. This result reflects the Greek consumers' behavior towards the organic products according to which they are used to pay more in order to buy fresh organic products hence the WTP for these products reflects the real and not just their hypothetical behavior.

Overall, these results should not be generalized arbitrarily, bearing in mind some limitations of our study. First, even though the design of the experiment permits us to replicate real choice conditions, the conditions of the study remain those of a laboratory experiment. Moreover, as in all surveys, sample representativeness is always of concern to the researcher. This sample does not claim to be representative of the Greek population, and therefore accepts the limitations regarding the extent to which our findings can be generalized to broader populations. 


\section{References}

Batte, M. T., Hooker, N. H., Haab, T. C., \& Beaverson, J. (2007). Putting their money where their mouths are: Consumer willingness to pay for multi-ingredient, processed organic food products. Food Policy, 32(2), 145-159.

Camacho-Cuena, E., García-Gallego, A., Georgantzís, N., \& Sabater-Grande, G. (2004). An experimental validation of hypothetical WTP for a recyclable product. Environmental and Resource Economics, 27(3), 313-335.

Camacho-Cuena, E., García-Gallego, A., Georgantzís, N., \& Sabater-Grande, G. (2003). An experimental test of response consistency in contingent valuation. Ecological Economics, 47(2-3), 167-182. doi: http://dx.doi.org/10.1016/S0921-8009(03)00192-7

Carboni, R., Vassallo, M., Conforti, P., \& D'Amicis, A. (2000). [A survey on consumption attitude-willingness to pay and organic product certification. Remarks and comments on obtained results]. Rivista di Scienza del'Alimentazione (Italy).

Chryssochoidis, G. (2000). Repercussions of consumer confusion for late introduced differentiated products. European journal of marketing, 34(5/6), 705-722.

Combris, P., Lecocq, S., \& Visser, M. (1997). Estimation of a hedonic price equation for Bordeaux wine: does quality matter? The Economic Journal, 390-402.

Conrad, L. (2002). The Myth of Consumerism: London, Sterling, Virgiana, Pluto Press.

Cummings, R. G., Brookshire, D. S., Bishop, R. C., \& Arrow, K. J. (1986). Valuing environmental goods: an assessment of the contingent valuation method: Rowman \& Littlefield Pub Incorporated.

Cummings, R. G., Harrison, G. W., Rutstr, xf, \& m, E. E. (1995). Homegrown Values and Hypothetical Surveys: Is the Dichotomous Choice Approach Incentive-Compatible? The American Economic Review, 85(1), 260-266.

Davies, A., Titterington, A. J., \& Cochrane, C. (1995). Who buys organic food? A profile of the purchasers of organic food in Northern Ireland. British Food Journal, 97(10), 17-23. 
European Commission Agriculture and Rural Development. (2010). The EU Organic Logo. Retrieved April, 2015, from http://ec.europa.eu/agriculture/organic/documents/logo/ user_manual_logo_en.pdf

European Commission Agriculture and Rural Development (2015). Organic Farming. Retrieved April, 2015, from http://ec.europa.eu/agriculture/organic/downloads/logo/ index_en.htm

Fotopoulos, C., \& Krystallis, A. (2002). Organic product avoidance: reasons for rejection and potential buyers' identification in a countrywide survey. British Food Journal, 104(3/4/5), 233-260.

Fotopoulos, C., \& Krystallis, A. (2002). Purchasing motives and profile of the Greek organic consumer: a countrywide survey. British Food Journal, 104(9), 730-765.

Govindasamy, R., \& Italia, J. (1999). Predicting willingness-to-pay a premium for organically grown fresh produce. Journal of Food Distribution Research, 30, 44-53.

Grunert, S. C., \& Juhl, H. J. (1995). Values, environmental attitudes, and buying of organic foods. Journal of Economic Psychology, 16(1), 39-62.

Hjelmar, U. (2011). Consumers' purchase of organic food products. A matter of convenience and reflexive practices. Appetite, 56(2), 336-344.

Krystallis, A., Fotopoulos, C., \& Zotos, Y. (2006). Organic Consumers' Profile and Their Willingness to Pay (WTP) for Selected Organic Food Products in Greece. Journal of International Consumer Marketing, 19(1), 81-106. doi: 10.1300/J046v19n01_05

Laroche, M., Bergeron, J., \& Barbaro-Forleo, G. (2001). Targeting consumers who are willing to pay more for environmentally friendly products. Journal of Consumer Marketing, 18(6), 503-520.

Latacz-Lohmann, U., \& Foster, C. (1997). From "niche" to "mainstream"-strategies for marketing organic food in Germany and the UK. British Food Journal, 99(8), 275-282.

Magnusson, M. K., Arvola, A., Hursti, U.-K. K., Åberg, L., \& Sjödén, P.-O. (2003). Choice of organic foods is related to perceived consequences for human health and to environmentally friendly behaviour. Appetite, 40(2), 109-117. 
Magnusson, M. K., Arvola, A., Koivisto Hursti, U.-K., Åberg, L., \& Sjödén, P.-O. (2001). Attitudes towards organic foods among Swedish consumers. British Food Journal, 103(3), 209-227.

McEachern, M., Seaman, C., Padel, S., \& Foster, C. (2005). Exploring the gap between attitudes and behaviour: Understanding why consumers buy or do not buy organic food. British Food Journal, 107(8), 606-625.

Midmore, P., Wier, M., \& Zanoli, R. (2006). Consumer attitudes towards the quality and safety of organic and low input foods.

Morrison, G. C. (1998). Understanding the disparity between WTP and WTA: endowment effect, substitutability, or imprecise preferences? Economics Letters, 59(2), 189-194. doi: http://dx.doi.org/10.1016/S0165-1765(98)00049-4

Nyborg, K. (2000). Homo Economicus and Homo Politicus: interpretation and aggregation of environmental values. Journal of Economic Behavior \& Organization, 42(3), 305-322. doi: http://dx.doi.org/10.1016/S0167-2681(00)00091-3

Reicks, M., Splett, P., \& Fishman, A. (1997). Shelf labeling of organic foods: effects on customer perceptions and sales: Retail Food Industry Center, University of Minnesota.

Saba, A., \& Messina, F. (2003). Attitudes towards organic foods and risk/benefit perception associated with pesticides. Food quality and preference, 14(8), 637-645.

Schifferstein, H. N., \& Ophuis, P. A. O. (1998). Health-related determinants of organic food consumption in the Netherlands. 1(3), 119-133.

Torjusen, H., Lieblein, G., Wandel, M., \& Francis, C. A. (2001). Food system orientation and quality perception among consumers and producers of organic food in Hedmark County, Norway. Food quality and preference, 12(3), 207-216.

Torjussen, H., Nyberg, A., \& Wandel, M. (1999). Organic food: Consumers' perceptions and dietary choices. A survey from the Stange and Hamar region. Rapport-Statens Institutt for Forbruksforskning (Norway).

Tranter, R., Bennett, R. M., Costa, L., Cowan, C., Holt, G., Jones, P., Vestergaard, J. (2009). Consumers' willingness-to-pay for organic conversion-grade food: Evidence from five EU countries. Food Policy, 34(3), 287-294. 
Tregear, A., Dent, J., \& McGregor, M. (1994). The demand for organically grown produce. British Food Journal, 96(4), 21-25.

Ureña, F., Bernabéu, R., \& Olmeda, M. (2008). Women, men and organic food: differences in their attitudes and willingness to pay. A Spanish case study. International Journal of Consumer Studies, 32(1), 18-26.

Vlosky, R. P., Ozanne, L. K., \& Fontenot, R. J. (1999). A conceptual model of US consumer willingness-to-pay for environmentally certified wood products. Journal of Consumer Marketing, 16(2), 122-140.

Williams, P. R., \& Hammitt, J. K. (2001). Perceived risks of conventional and organic produce: pesticides, pathogens, and natural toxins. Risk analysis, 21(2), 319-330.

Wood, W., \& Neal, D. T. (2009). The habitual consumer. Journal of Consumer Psychology, 19(4), 579-592.

Zotos, Y., \& Ziamou, P. (1999). Marketing Organically Produced Food Products in Greece. Greener Management International(25). 


\subsection{Appendix}

\section{Instructions (translated from Greek)}

Thank you for your participation in this experiment. The goal of this experiment is to study the economic behavior of consumers under a specific scenario. The instructions are easy to follow and there is a chance to win an amount of money in a confidential manner, given that none of the other participants will have any information on the amount of money you have gained. In this experiment there are no solidly correct or wrong answers. However, keep in mind that your decisions will affect the amount of money you gain. You can ask the experimenter in case you have any doubts about the process of the experiment by raising your hand. The procedure of the experiment is as follows:

1. You are requested to fill in the following short questionnaire at your own discretion. Remember that there are no correct and wrong answers.

\section{QUESTIONNAIRE PART I.}

\section{How important are environmental issues to you?}

$\square$ Very Important $\square$ Important $\square$ Neither important, nor unimportant $\square$ Unimportant $\square$ Very Unimportant

2. Are you member of any associations devoted to the protection of the natural environment?

$\square$ No $\square$ Yes (Please specify in which one)

3. How informed are you on the procedure of the production of organic agricultural products?

$\square$ Very informed $\square$ Informed $\square$ Neither informed, nor uniformed $\square$ Uniformed $\square$ Very uninformed

4. How often do you buy organic products?

$\square$ Never $\square$ Scarcely $\square$ Sometimes $\square$ often $\square$ Always

5. What is your English language level?

$\square$ Level A1 "Elementary knowledge"

$\square$ Level A2 "Pre-Intermediate knowledge"

Level B1 "Intermediate knowledge" 
$\square$ Level B2 "Upper intermediate knowledge"

$\square$ Level C1 "Advanced knowledge"

$\square$ Level C2 "Proficient knowledge"

6. Gender: $\square$ Male $\square$ Female

7. Age:

8. Annual family income (in $€$ ):

A. $\square$ No income

B. $\square 1-7.000$

C. $\square 7.001-14.000$

D. $\square 14.001-21.000$

E. $\square 21.001-28.000$

F. $\square 28.001-42.000$

G. $\square$ 42.001-56.000

H. $\square$ 56.001-70.000

I. $\square>70.000$ 
2. Thank you very much for your answers. Now you are asked to fill in the following questionnaire concerning the willingness to pay for two different samples of table olives. The only difference between the two samples is that the first contains conventional table olives, while the second contains organic table olives and (possibly) their cost. Feel free to read about the characteristics of each sample in the following brochure in which you can see photos of the product described. (The experimenter shows the participant the real product along with the questionnaire)

\section{QUESTIONNAIRE PART II}

\begin{tabular}{|c|c|}
\hline Conventional table olives & Organic table olives \\
\hline $\begin{array}{l}\text { The two products are identical, except for the } \\
\text { characteristics described below }\end{array}$ & \\
\hline Characteristics & Characteristics \\
\hline $\begin{array}{l}\checkmark \quad \text { The production follows the } \\
\text { European Directive on integrated } \\
\text { production of olives. } \\
\checkmark \\
\text { The production follows an } \\
\text { intensive cultivation method of } \\
\text { high inflows } \\
\checkmark \quad \begin{array}{l}\text { The use of synthetic-chemical / } \\
\text { inorganic-nitrogen fertilizers is } \\
\text { permitted }\end{array} \\
\checkmark \quad \text { It is permitted to use herbicides / } \\
\text { insecticides }\end{array}$ & 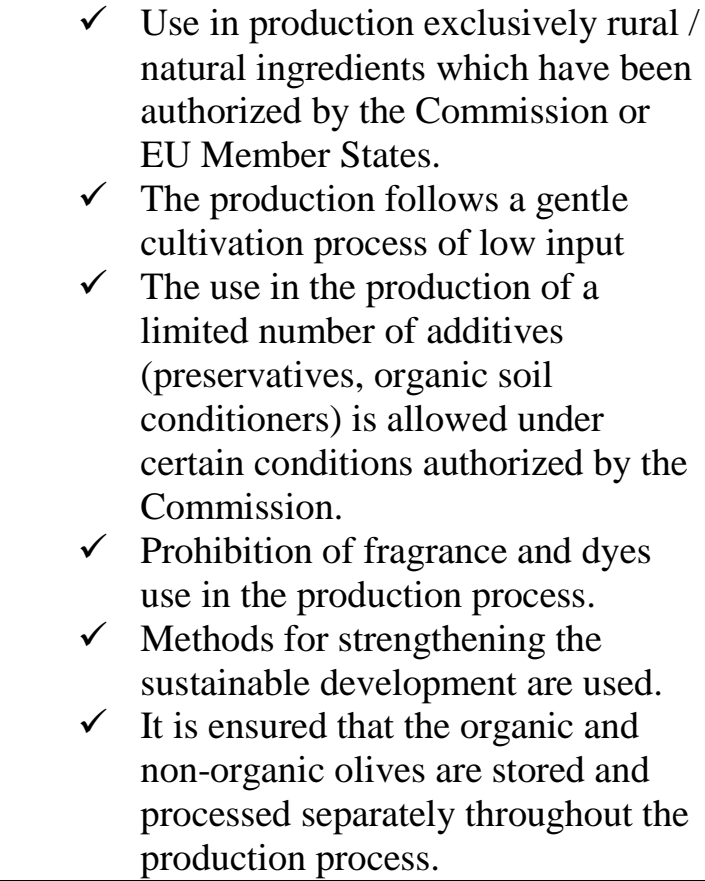 \\
\hline
\end{tabular}

We will now show you fifteen (15) price-scenarios. For every pair of prices you are asked to make your purchase decision (between Conventional or Organic table olives) and mark only one of the products in each scenario.

\begin{tabular}{|c|c|c|c|c|}
\hline Prices & A) Conventional & B) Organic Olives & A) Conventional & B) Organic Olives \\
\hline \hline Scenario 1. & $1.80 €$ & $1.00 €$ & $\square$ & $\square$ \\
\hline Scenario 2. & $1.80 €$ & $1.20 €$ & $\square$ & $\square$ \\
\hline Scenario 3. & $1.80 €$ & $1.40 €$ & $\square$ & $\square$ \\
\hline Scenario 4. & $1.80 €$ & $1.60 €$ & $\square$ & $\square$ \\
\hline Scenario 5. & $1.80 €$ & $1.80 €$ & $\square$ & $\square$ \\
\hline Scenario 6. & $1.80 €$ & $2.00 €$ & $\square$ & $\square$ \\
\hline
\end{tabular}




\begin{tabular}{|c|c|c|c|c|}
\hline Scenario 7. & $1.80 €$ & $2.20 €$ & $\square$ & $\square$ \\
\hline Scenario 8. & $1.80 €$ & $2.40 €$ & $\square$ & $\square$ \\
\hline Scenario 9. & $1.80 €$ & $2.60 €$ & $\square$ & $\square$ \\
\hline Scenario 10. & $1.80 €$ & $2.80 €$ & $\square$ & $\square$ \\
\hline Scenario 11. & $1.80 €$ & $3.00 €$ & $\square$ & $\square$ \\
\hline Scenario 12. & $1.80 €$ & $3.20 €$ & $\square$ & $\square$ \\
\hline Scenario 13. & $1.80 €$ & $3.40 €$ & $\square$ & $\square$ \\
\hline Scenario 14. & $1.80 €$ & $3.60 €$ & $\square$ & $\square$ \\
\hline Scenario 15. & $1.80 €$ & $3.80 €$ & $\square$ & $\square$ \\
\hline
\end{tabular}


3. Thank you for your answers. Now you have an initial endowment of $5 €$. You should use this endowment to buy one unit of anyone of the two goods: "Conventional table olives" and "Organic table olives", both described in the brochure attached to this instruction sheet. As you will see, the only difference between these two products is that one of them is an organic product while the other one is not (and possibly their prices). You can study the characteristics of each sample in the following brochure in which you can see photos of the product described. (The experimenter shows the participant the real product along with the questionnaire)

\section{QUESTIONNAIRE PART III}

\begin{tabular}{|c|c|}
\hline Conventional table olives & Organic table olives \\
\hline $\begin{array}{l}\text { The two products are identical, except for the } \\
\text { characteristics described below }\end{array}$ & \\
\hline Characteristics & Characteristics \\
\hline $\begin{array}{l}\checkmark \quad \text { The production follows the } \\
\text { European Directive on integrated } \\
\text { production of olives. } \\
\checkmark \quad \text { The production follows an } \\
\text { intensive cultivation method of } \\
\text { high inflows } \\
\checkmark \quad \text { The use of synthetic-chemical / } \\
\text { inorganic-nitrogen fertilizers is } \\
\text { permitted } \\
\checkmark \text { It is permitted to use herbicides / } \\
\text { insecticides }\end{array}$ & 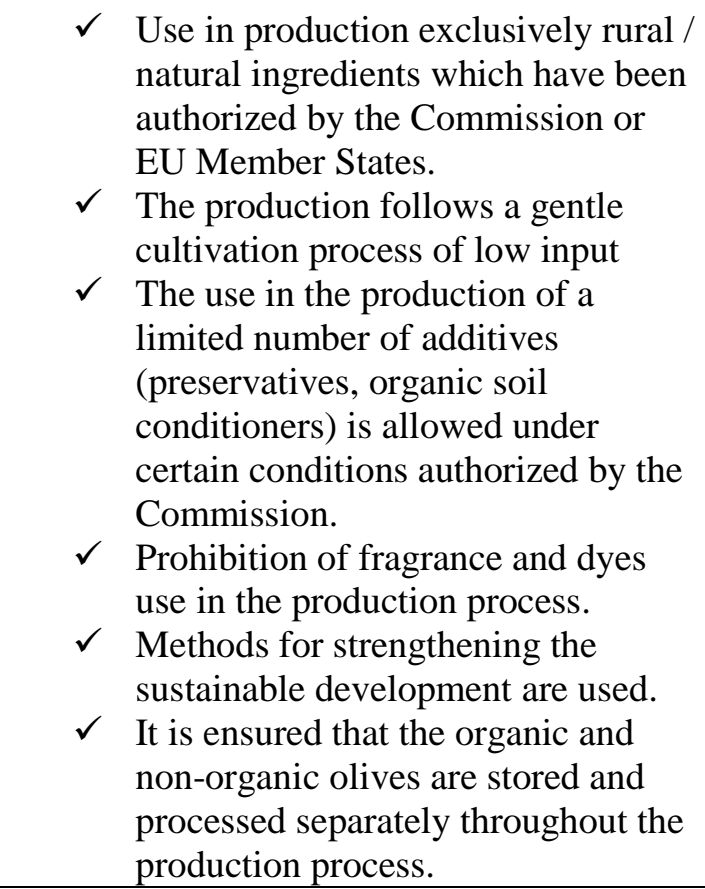 \\
\hline
\end{tabular}

We will now show you fifteen (15) price-scenarios. Make your purchase decision (Conventional or Organic table olives) for every pair of prices and mark only one of the products in each scenario.

\begin{tabular}{|c|c|c|c|c|}
\hline Prices & A) Conventional & B) Organic Olives & A) Conventional & B) Organic Olives \\
\hline \hline Scenario 1. & $1.80 €$ & $1.00 €$ & $\square$ & $\square$ \\
\hline Scenario 2. & $1.80 €$ & $1.20 €$ & $\square$ & $\square$ \\
\hline Scenario 3. & $1.80 €$ & $1.40 €$ & $\square$ & $\square$ \\
\hline Scenario 4. & $1.80 €$ & $1.60 €$ & $\square$ & $\square$ \\
\hline Scenario 5. & $1.80 €$ & $1.80 €$ & $\square$ & $\square$ \\
\hline Scenario 6. & $1.80 €$ & $2.00 €$ & $\square$ & $\square$ \\
\hline
\end{tabular}




\begin{tabular}{|c|c|c|c|c|}
\hline Scenario 7. & $1.80 €$ & $2.20 €$ & $\square$ & $\square$ \\
\hline Scenario 8. & $1.80 €$ & $2.40 €$ & $\square$ & $\square$ \\
\hline Scenario 9. & $1.80 €$ & $2.60 €$ & $\square$ & $\square$ \\
\hline Scenario 10. & $1.80 €$ & $2.80 €$ & $\square$ & $\square$ \\
\hline Scenario 11. & $1.80 €$ & $3.00 €$ & $\square$ & $\square$ \\
\hline Scenario 12. & $1.80 €$ & $3.20 €$ & $\square$ & $\square$ \\
\hline Scenario 13. & $1.80 €$ & $3.40 €$ & $\square$ & $\square$ \\
\hline Scenario 14. & $1.80 €$ & $3.60 €$ & $\square$ & $\square$ \\
\hline Scenario 15. & $1.80 €$ & $3.80 €$ & $\square$ & $\square$ \\
\hline
\end{tabular}

At the end of the session, a lottery will be drawn for each participant so as to decide which one of the fifteen pairs of prices corresponds to the scenario you will actually be faced with. Your actual earnings depend on the strategy chosen in the scenario drawn in the lottery.

Your payment, at the end of this part of the experiment, will be the difference between your initial endowment and the price corresponding to the product you have chosen for the scenario drawn in the lottery (for example $5-1.80=3.20 €$ ). You will also be given the product you previously chose to buy. 